\title{
Macroeconomic Stability in Developing Countries: How Much Is Enough?
}

\author{
Peter Montiel and Luis Servén *
}

\begin{abstract}
In the 1990s macroeconomic policies improved in a majority of developing countries, but the growth dividend from such improvement fell short of expectations, and a policy agenda focused on stability turned out to be associated with a multiplicity of financial crises. This paper takes a retrospective look at the contents and implementation of the macroeconomic reform agenda of the 1990s. It reviews the progress achieved with fiscal, monetary and exchange rate policies across the developing world, and the effectiveness of the changing policy framework in promoting stability and growth. The main lesson is that slow growth and frequent crises resulted, more often than not, from shortcomings in the reform agenda of the 1990s. These shortcomings essentially concern the depth and breadth of the macro reform agenda, its attention to macro vulnerabilities, and the complementary reforms outside the macroeconomic sphere.
\end{abstract}

JEL Classification: E52, E62, F32, F34, F43

World Bank Policy Research Working Paper 3456, November 2004

The Policy Research Working Paper Series disseminates the findings of work in progress to encourage the exchange of ideas about development issues. An objective of the series is to get the findings out quickly, even if the presentations are less than fully polished. The papers carry the names of the authors and should be cited accordingly. The findings, interpretations, and conclusions expressed in this paper are entirely those of the authors. They do not necessarily represent the view of the World Bank, its Executive Directors, or the countries they represent. Policy Research Working Papers are available online at http://econ.worldbank.org.

\footnotetext{
* Montiel: Williams College, Department of Economics. Address: Fernald House Williamstown, MA 01267. Email: peter.j.montiel@williams.edu. Servén: The World Bank. Address: 1818 H St. NW, Washington, DC 20433. E-mail: 1serven@worldbank.org. This paper was originally prepared as background for the World Bank report "Economic Growth in the 1990s: Learning from a Decade of Reform," whose complete draft is available at http://www1.worldbank.org/prem/lessons1990s/countrynotes.htm. We are indebted to Roberto Zagha for numerous comments and discussions throughout the preparation of the paper. We thank, without implication, Indermit Gill, Jim Hanson, Ricardo Hausmann, Ravi Kanbur, Phil Keefer, Guillermo Perry, Lant Pritchett and S. Ramachandran for valuable comments on previous versions. Patricia Macchi provided excellent research assistance.
} 


\section{Introduction}

Among developing countries, the decade of the 1990s was characterized by two major macroeconomic developments. Macroeconomic policies, as traditionally measured, improved in a majority of countries, but the growth benefits expected from the adoption of better policies failed to materialize -- at least to the extent expected by many observers. In addition, despite the improvement in macroeconomic policies the decade witnessed a proliferation of financial crises that in many cases had severe adverse effects on economic growth and poverty in the countries involved.

What is the relationship between these two developments? This paper argues that both slow growth and multiple crises were symptomatic of deficiencies in the design and execution of the pro-growth reform strategy adopted in the 1990s, of which macroeconomic stability was viewed as the centerpiece. ${ }^{1}$

Specifically, the paper's contention is that, from a growth-enhancing perspective, the gains in macroeconomic stability achieved during the 1990s were limited on several counts:

i. Improvements in macroeconomic stability were far from universal. While this is hardly surprising, the consequence is that macro instability continued to impede growth in some countries and allowed traditional macro imbalances to generate crises during the 1990s similar in many ways to those of the 1980 s.

ii. Gains in macroeconomic policy realizations were much more widespread than those achieved in reforming the rules and institutions governing the formulation of macro policies. Such reforms ultimately determine whether policy improvements will be longlasting -- and will be perceived as such by the private sector. The limited progress on that front likely undermined the contribution of macro policy improvements -- even where they could indeed have been sustained ex post -- to raising economic growth.

iii. Even in countries that took radical steps toward macroeconomic stabilization, the macroeconomic agenda of the 1990 s tended to be incomplete, in that it failed to address macroeconomic fragilities -- most notably those arising from the financial system and the capital account. Inappropriate policies toward the domestic financial sector and the capital account of the balance of payments left many stabilizing economies highly vulnerable to adverse shocks and proved to be the Achilles heel of macroeconomic stability in some of the most important crises of the 1990s.

iv. Finally, but perhaps most importantly, gains in macroeconomic stability were often not complemented with necessary growth-enhancing reforms in other parts of the economy. To put it differently, the growth payoff of macroeconomic stability per se may have been oversold. Macro instability hampers investors' ability and willingness to undertake investment opportunities -- understood in the broadest sense of the term. But

\footnotetext{
${ }^{1}$ Easterly (2001) also states the view that the multiple crises of the 1990s represent a symptom of, rather than an "explanation" for, the slow growth of the 1990s.
} 
for macro stability to deliver growth, those opportunities must exist in the first place. Their creation is a task that belongs mainly to other areas of reform - specifically to microeconomic reforms and to a variety of institutional reforms. In short, macro stability can help, but it cannot by itself deliver growth.

In a nutshell, our argument is that while slow growth and frequent crises reflected insufficient policy improvement in some cases, more generally these phenomena resulted from shortcomings in the reform agenda of the 1990s -- in terms of the depth of macro reforms, the avoidance of macro fragilities and the overall breadth of the reform agenda. The rest of this paper develops this argument by taking a retrospective look at the macroeconomic reform agenda of the 1990s. Section II reviews progress in implementing the reform agenda during the past decade. Section III evaluates the effectiveness of what was done from the perspective of promoting economic growth and discusses how a policy agenda focused on macroeconomic stability turned out to be associated with a multiplicity of crises. Finally, Section IV examines the lessons that can be drawn from the experience of the 1990s. These lessons essentially concern the depth and breadth of the macro reform agenda, its attention to macro vulnerabilities, and the importance of complementary reforms outside the macroeconomic sphere.

\section{The Facts of the 1990s}

How did macroeconomic stability evolve over the 1990s? Answering this question requires first a clarification of the meaning of macroeconomic stability and of the way to measure it empirically. Conceptually, macroeconomic instability refers to phenomena that decrease the predictability of the domestic macroeconomic environment, and it is of concern because unpredictability hampers resource-allocation decisions, investment and growth. ${ }^{2}$

Macroeconomic instability can take the form of volatility of key macroeconomic variables or of unsustainability in their behavior (which predicts future volatility). This section examines the gains in macroeconomic stability achieved by developing countries during the 1990s by looking at the behavior of macroeconomic outcome variables such as the rate of growth of real output, the rate of inflation and the current account deficit. The scrutiny focuses on the volatility of the growth rate and the levels of inflation and the current account deficit. ${ }^{3}$ But observed changes in the behavior of these endogenous variables can reflect changes in the macroeconomic policy environment and/or exogenous shocks. To sort out the roles of these two factors, the review looks separately at the behavior of macroeconomic policy variables -- capturing fiscal, monetary and

\footnotetext{
${ }^{2}$ In recent years there has been a renewal of interest, sparked by Ramey and Ramey (1995), in the adverse effects that real and nominal instability can have on economic growth, as documented by a growing empirical literature on the subject. For a recent evaluation, see Hnatkovska and Loayza (2004).

${ }^{3}$ The level of inflation is strongly associated with its volatility, as well as with the volatility of (inter- and intra-temporal) relative prices. For these reasons, and because high levels of inflation are likely to be viewed as unsustainable, inflation itself is commonly taken as a summary indicator of instability. In turn, the external current-account deficit is commonly viewed as a leading indicator of future instability, with excessively large -- and thus unsustainable -- deficits often predicting an impeding macroeconomic crisis.
} 
exchange rate policies -- as well as that of exogenous shocks to developing countries, both real and financial. In the case of the policy variables, the assessment concerns whether the policy configuration tended to evolve toward a fiscal stance safely consistent with solvency, a monetary policy stance consistent with a low and stable rate of inflation, and a robust (non-crisis prone) exchange rate regime that avoids persistent under- or over-valuation of the currency as well as excessive volatility of the real exchange rate. The discussion of external shocks assesses whether developing countries faced a more or less challenging (unstable) external environment in the 1990s than in previous decades.

\section{II.1 Stability of Macroeconomic Outcomes}

By either of the measures mentioned above, developing countries have traditionally been characterized by a much higher degree of macroeconomic instability than industrial economies, and there is a widespread perception that the problem has been getting worse. ${ }^{4}$ In spite of that perception, however, the volatility of key macroeconomic aggregates actually declined in the 1990 s across the developing world. ${ }^{5}$ For example, the standard deviation of per-capita GDP growth fell from 4 percent in the 1970s and 1980s to about 3 percent in the 1990s, although it still remained significantly above the comparable figure for industrial economies (1.5 percent) (Figure II.1). ${ }^{67}$ The reduction in GDP volatility was widespread, but far from universal: of the 77 developing countries for which complete information is available over the period 1960-2000, approximately one third (27 countries) experienced an increase in growth volatility in the 1990s relative to the 1980 s.

It is worth noting that the decline in aggregate volatility extends also to other variables more directly related to individuals' welfare, such as income and consumption growth, although to varying extents. In particular, the volatility of private consumption growth also declined relative to the previous decade, but mainly in low-income developing countries. In middle-income countries consumption volatility remained virtually unchanged at the record-highs of the $1980 \mathrm{~s}^{8}$

\footnotetext{
${ }^{4}$ See IADB (1995), De Ferranti et al (2000) and Easterly, Islam and Stiglitz (2001). The popular view that instability is on the rise is documented by Rodrik (2001).

${ }^{5}$ Here the focus is on a sample of 97 countries with population above 500,000 possessing complete information on real GDP growth over the period 1960-2000. The population lower limit is set to exclude highly volatile island economies. The total sample includes 20 industrial and 77 developing economies, of which three (Israel, Hong Kong and Singapore) are higher-income non-OECD countries.

${ }^{6}$ The decline in developing-country volatility over the 1990s is documented also by Rodrik (2001), De Ferranti et al (2000) and Hnatkovska and Loayza (2004). The same result holds if volatility is measured by a robust statistic such as the inter-quartile range instead of the standard deviation.

${ }^{7}$ The decline in volatility was statistically significant: formal tests strongly reject the hypothesis that the cross-country distribution of growth volatility did not change between the 1980s and 1990s, as well as the hypothesis that the changes in volatility across the two decades are centered at zero.

${ }^{8}$ The information on private consumption is available only for a slightly smaller country sample. The fact that consumption volatility declined less than income and output volatility in the 1990s is also underscored by Kose, Prasad and Terrones (2003), and has been viewed as a failure of financial openness to provide the consumption-smoothing mechanism predicted by conventional theory.
} 
Figure II.1: GDP Growth Volatility

(percent, medians by income group)

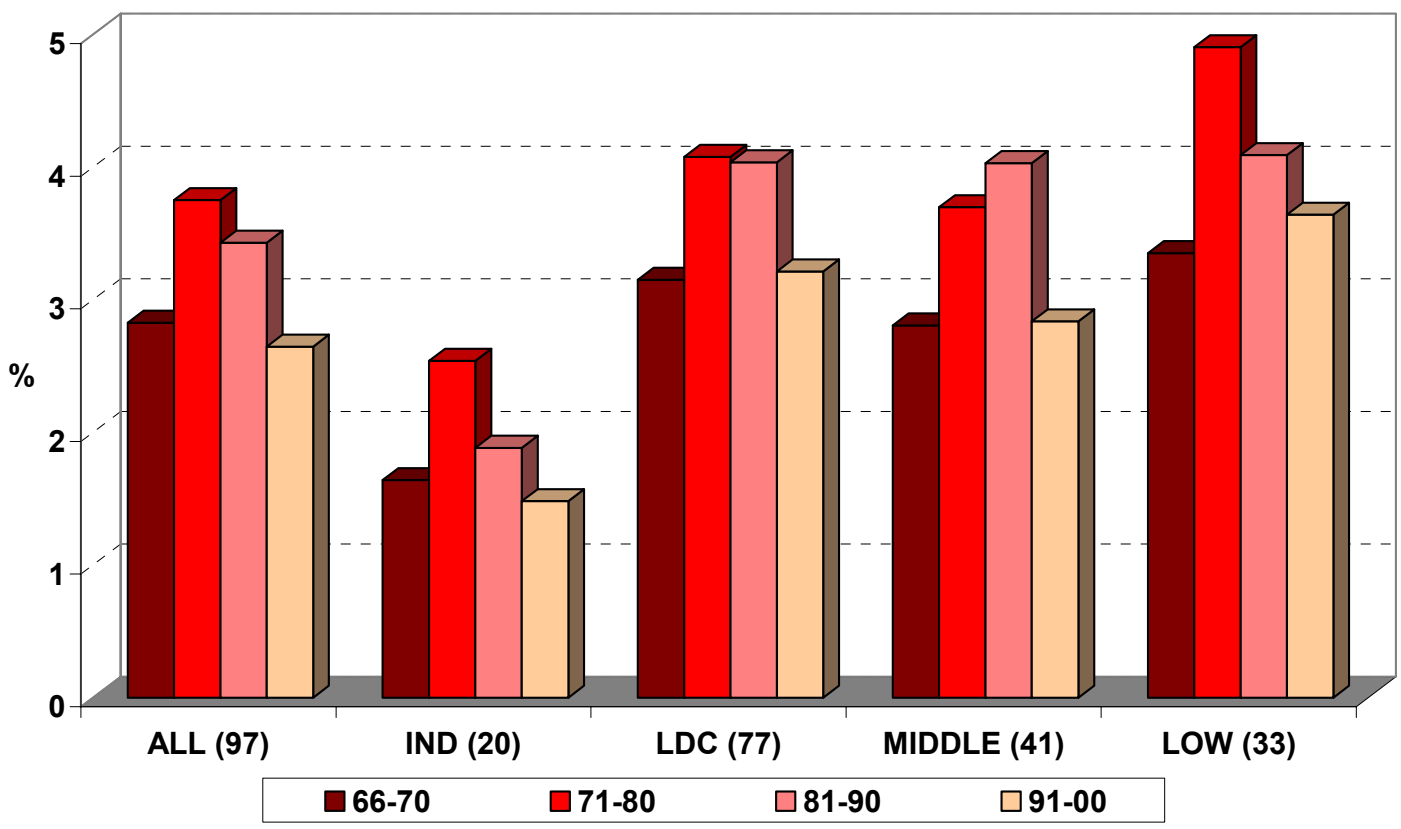

Sources: WDI-WB; Hnatkovska and Loayza (2004).

However, the reduction in aggregate output volatility concealed the increasing role of extreme instability. Large growth disturbances accounted in the 1990s for a higher proportion of overall instability than in previous decades. This was due to the increased contribution of large negative shocks, which in the last decade accounted for close to one-fourth of total growth volatility, against 14 percent in the 1960s and 1970s and 18 percent in the 1980s (Figure II.2). ${ }^{9}$ The increasing incidence of growth crises affected not only countries that suffered rising volatility (such as Indonesia, Malaysia and Korea) but also countries whose growth volatility declined in the 1990s. This was the case, for example, of Madagascar (which suffered a large drop in GDP in 1991), Mexico and Ecuador.

\footnotetext{
${ }^{9}$ Negative extreme shocks also accounted for a larger fraction of the total volatility of gross national income and consumption in the 1990s than in previous decades. In technical terms, the frequency distribution of growth rates shows heavier left tails in the 1990s. For both GDP and consumption growth, this is confirmed by conventional skewness statistics.
} 
Figure II.2. Structure of GDP Growth Volatility

(percent, mean of 77 developing countries)

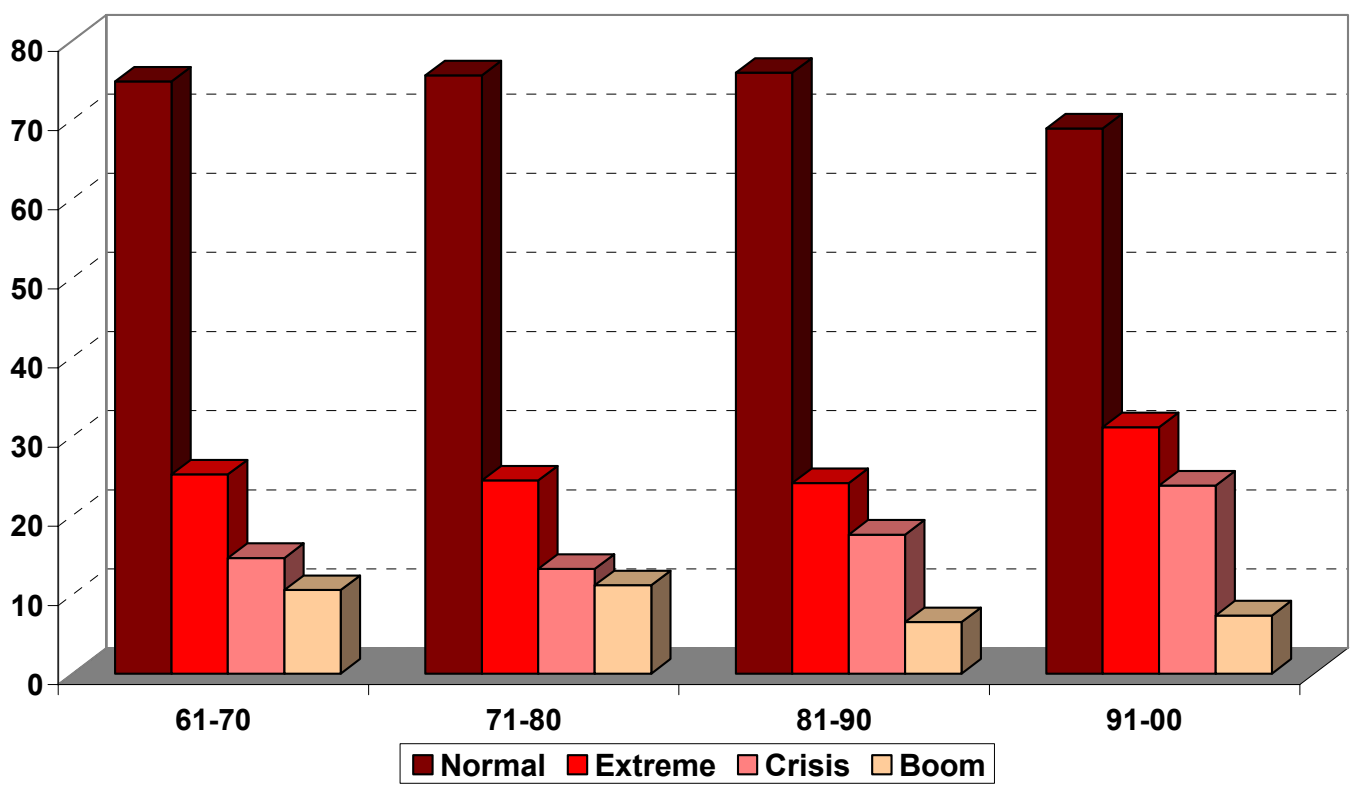

Sources: Hnatkovska and Loayza (2004); authors' calculations.

Notes: Total volatility $=$ Normal + Extreme; Extreme $=$ Crisis + Boom. Extreme shocks are defined as those exceeding two standard deviations of output growth over the respective decade.

Aside from output volatility, other key outcome variables commonly taken as indicators of aggregate stability exhibited an improving pattern in the 1990s. For example, the median inflation rate across middle-income developing countries declined from a peak of 16 percent in 1990 to 6 percent in 2000. Among low-income countries, inflation peaked in 1994-95, in the wake of the devaluation of the CFA franc, and then followed a declining pattern (Figure II.3). Yet over most of the 1990s, the gap between industrial and developing country median inflation rates remained substantial by the standards of the 1960s and 1970s.

Likewise, the incidence of high inflation among developing countries peaked in 1991, and then declined sharply (Figure II.4). However, the decline only took hold in the mid-1990s, and thus the number of developing countries (among those with complete data) experiencing average inflation above 50 percent over the decade as a whole was unchanged between the 1980s and the 1990s.

Other things equal, reduced aggregate volatility and lower inflation likely had a positive impact on the incomes of the poor. The inflation tax tends to fall disproportionately on lower income households, who hold few or no financial assets offering shelter against rising prices, and whose wage earnings typically are not fully indexed to inflation. Likewise, through this and other channels, higher aggregate volatility is empirically associated with worsening income distribution. ${ }^{10}$

\footnotetext{
${ }^{10}$ On the relation between macroeconomic volatility and poverty, see Laursen and Mahajan (2004). The impact of inflation on the poor is investigated by Easterly and Fischer (2001).
} 
Figure II.3: Inflation Rates, 1961-2000

(GDP deflator, medians by country income group)

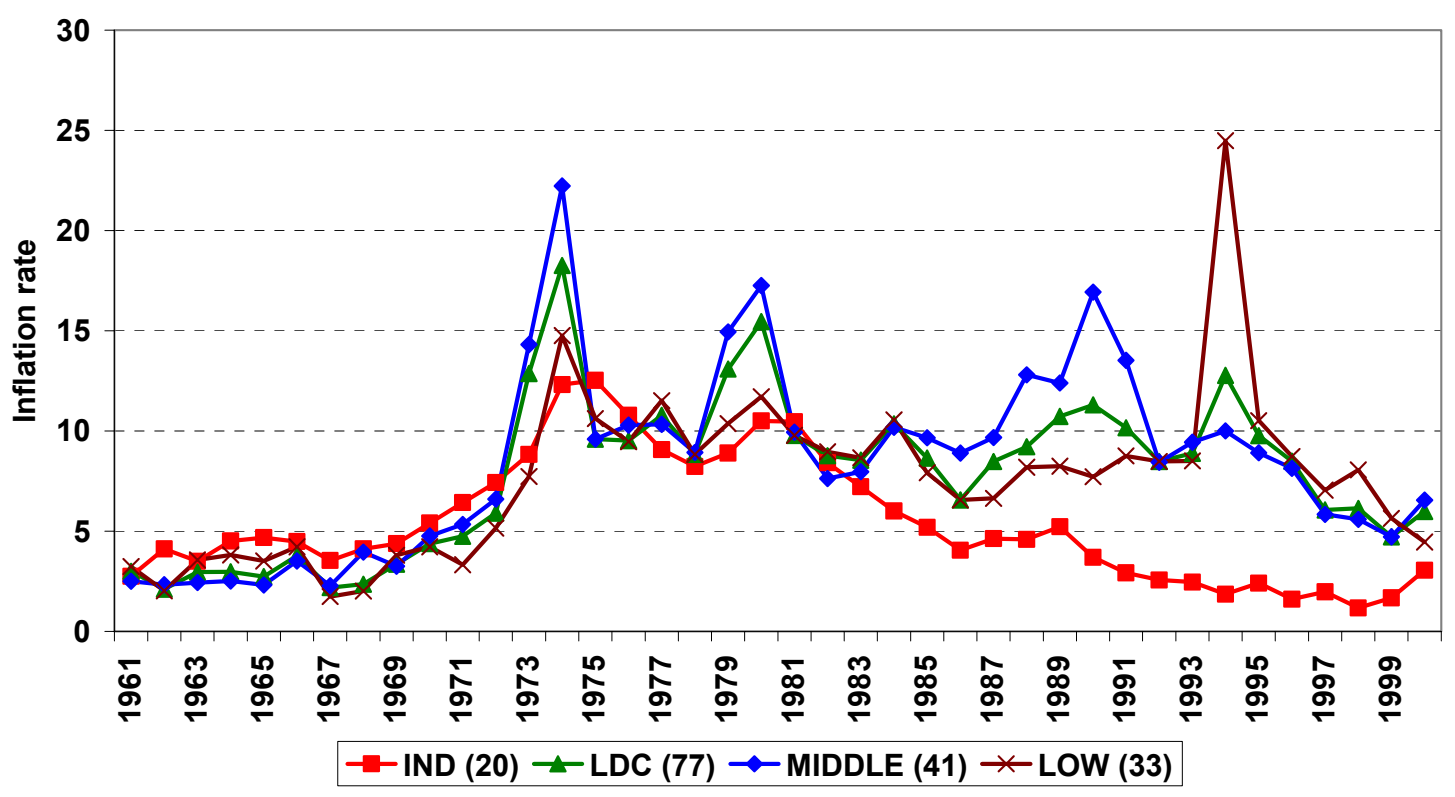

Source: WDI-WB.

Figure II.4: High Inflation in Developing Countries, 1961-2000 (relative frequency, percent)

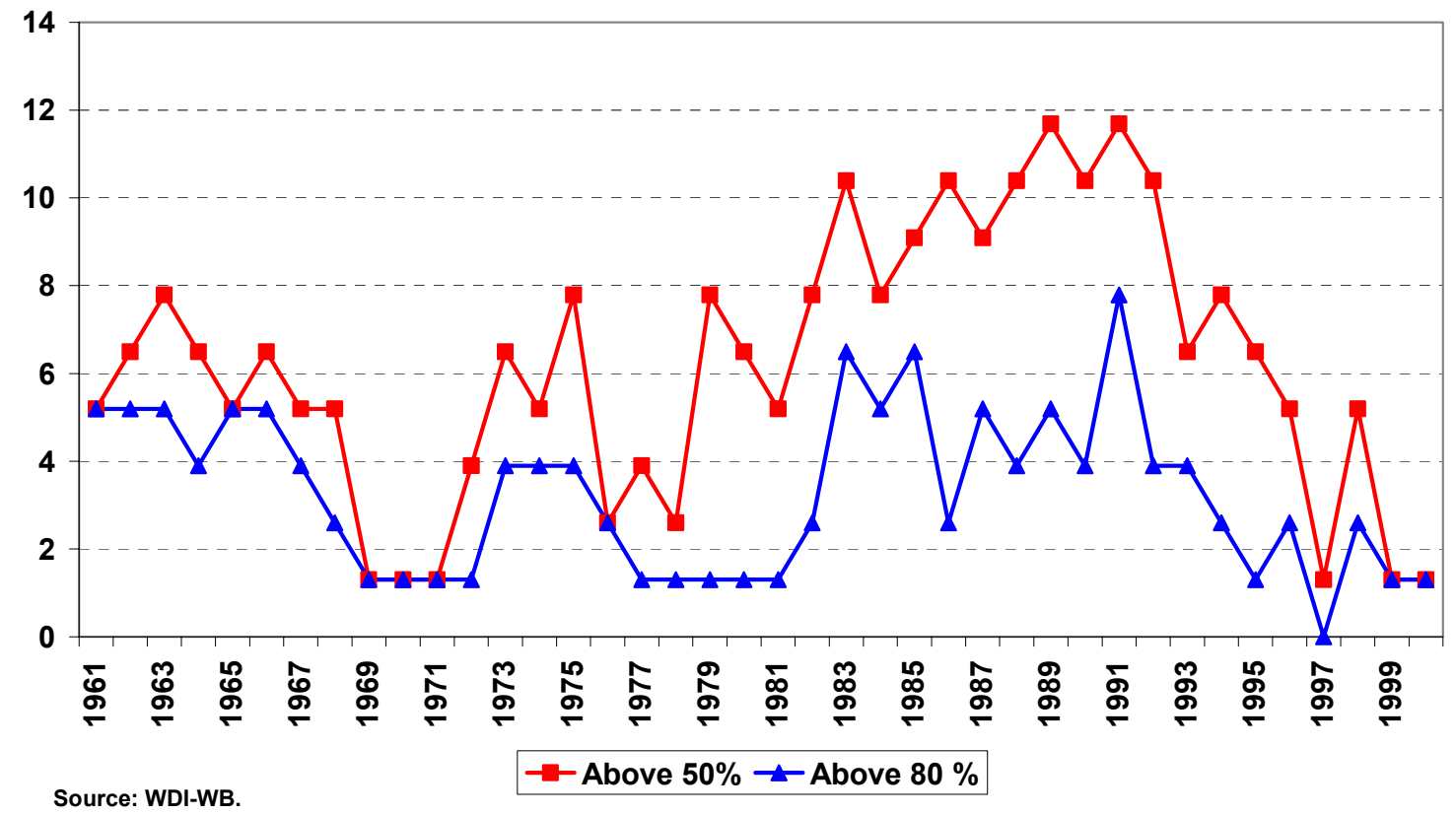


In turn, median current account deficits among developing countries increased slightly in the 1990s, although there was a contrast between middle and low-income developing economies. ${ }^{11}$ In the former, the median current account deficit/GDP ratio fell by about one percentage point relative to the 1970 s and 1980 s. $^{12}$ In the latter, it rose by about half a point vis-à-vis the 1980s to exceed 5 percent of GDP in the 1990s (Figure II.5).

Figure II.5: Current Account (percent of GDP, medians by country income group)

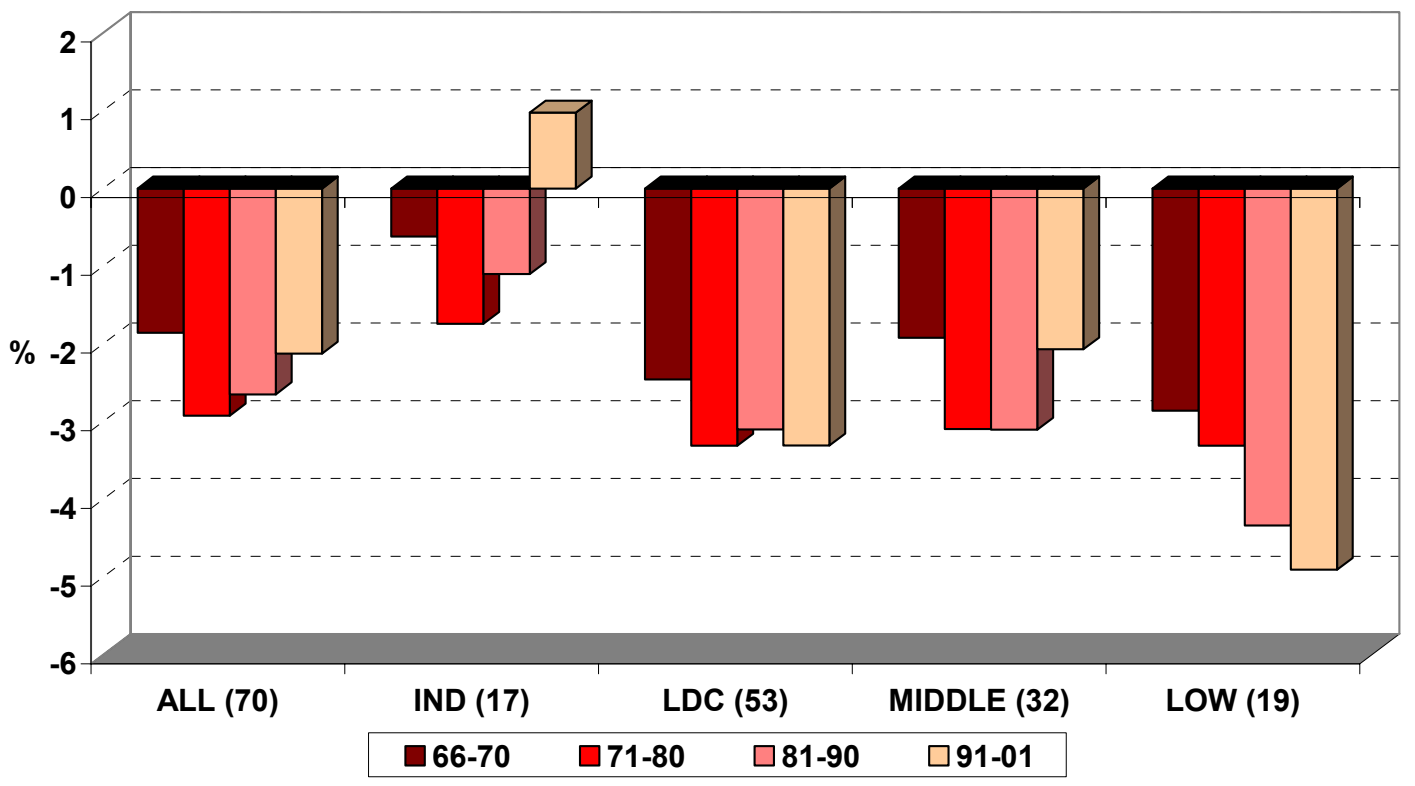

Sources: WDI-WB and BoP4-IMF.

Note: The countries featured are those for which data are available over the entire period shown.

\section{II.2 Policy Stability}

Conventional indicators of policy stability also showed an improvement over the 1990s. Most notably, the overall fiscal deficit fell across the developing world from a median value of 6-7 percent of GDP in the early 1980s to 2 percent of GDP in the 1990s before rebounding to about 3 percent by the end of the decade. The fiscal correction was particularly pronounced among middle-income countries. (Figure II.6).

\footnotetext{
${ }^{11}$ The availability of data on the other indicators presented in the rest of this section is in general much more limited than in the case of growth and inflation. For this reason, the figures below refer to the universe of countries for which information on the variable of interest is available over the entire period shown. This set varies across different variables, and therefore the conclusions of the analysis have to be taken with some caution.

${ }^{12}$ In part, however, this apparent improvement reflects the "sudden stop" of capital inflows to crisisafflicted emerging-market economies.
} 
Figure II.6: Developing Countries' Overall Fiscal Balance

(percent of GDP, medians by country income group)

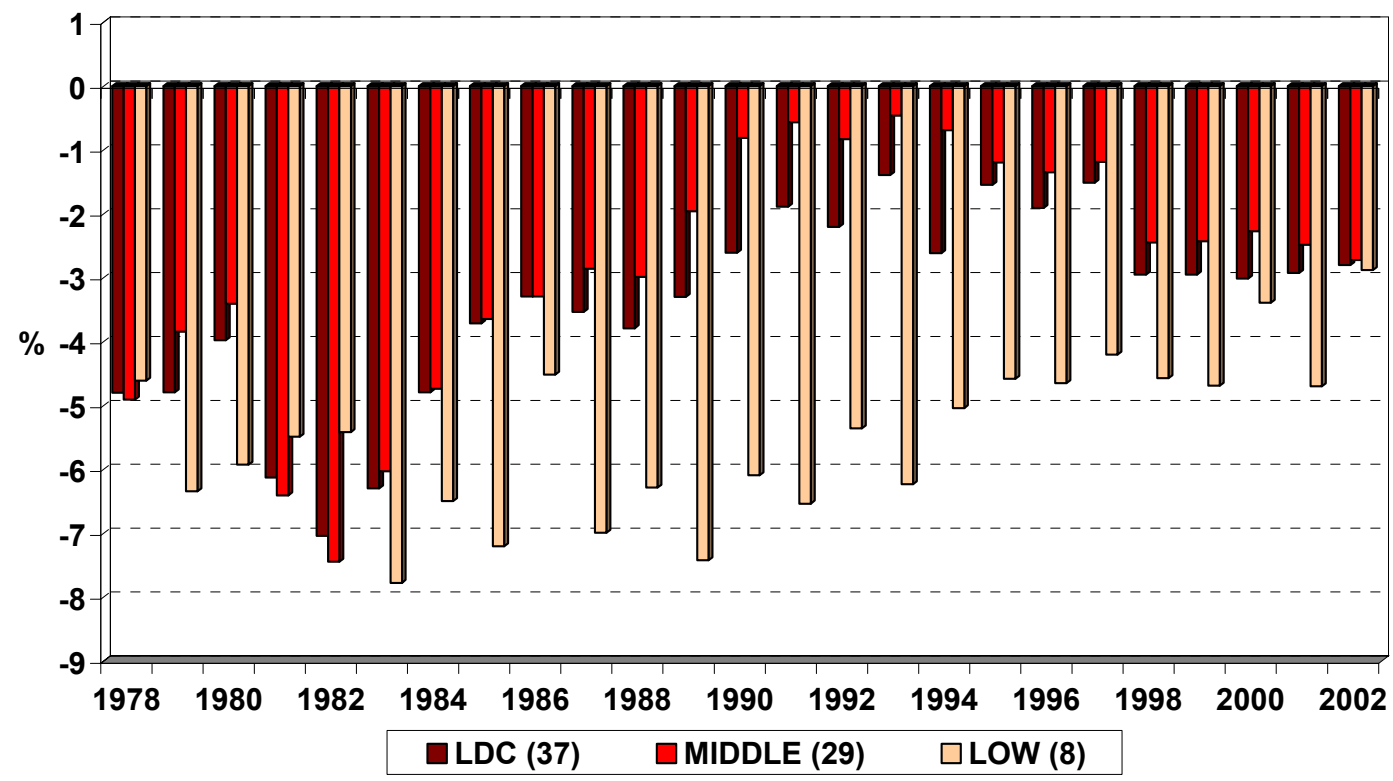

Sources: WDI-WB and IIF.

Note: The countries featured are those for which complete data are available from late 1970s on. The availability of consistent fiscal balance data is very limited, particularly for low-income countries.

However, the overall balance is affected by the trajectory of interest rates on public debt, which is beyond the direct control of the authorities, and thus the primary balance likely offers a more accurate measure of fiscal stance. Its evolution over the 1990s, shown in Figure II.7, displays a clear trend in the direction of increasing surpluses, particularly after 1995. By the end of the decade, the median developing country showed a primary surplus -- although a much more modest one than that of industrial countries. ${ }^{13}$

\footnotetext{
${ }^{13}$ Other measures of fiscal policy stability also showed an improvement. For example, the volatility of public spending (as measured by the standard deviation of public consumption growth) declined sharply among middle-income countries. Among lower-income economies, however, it showed little change relative to previous decades.
} 
Figure II.7: Primary Fiscal Balance, 1990-2002

(percent of GDP, medians by country income group)

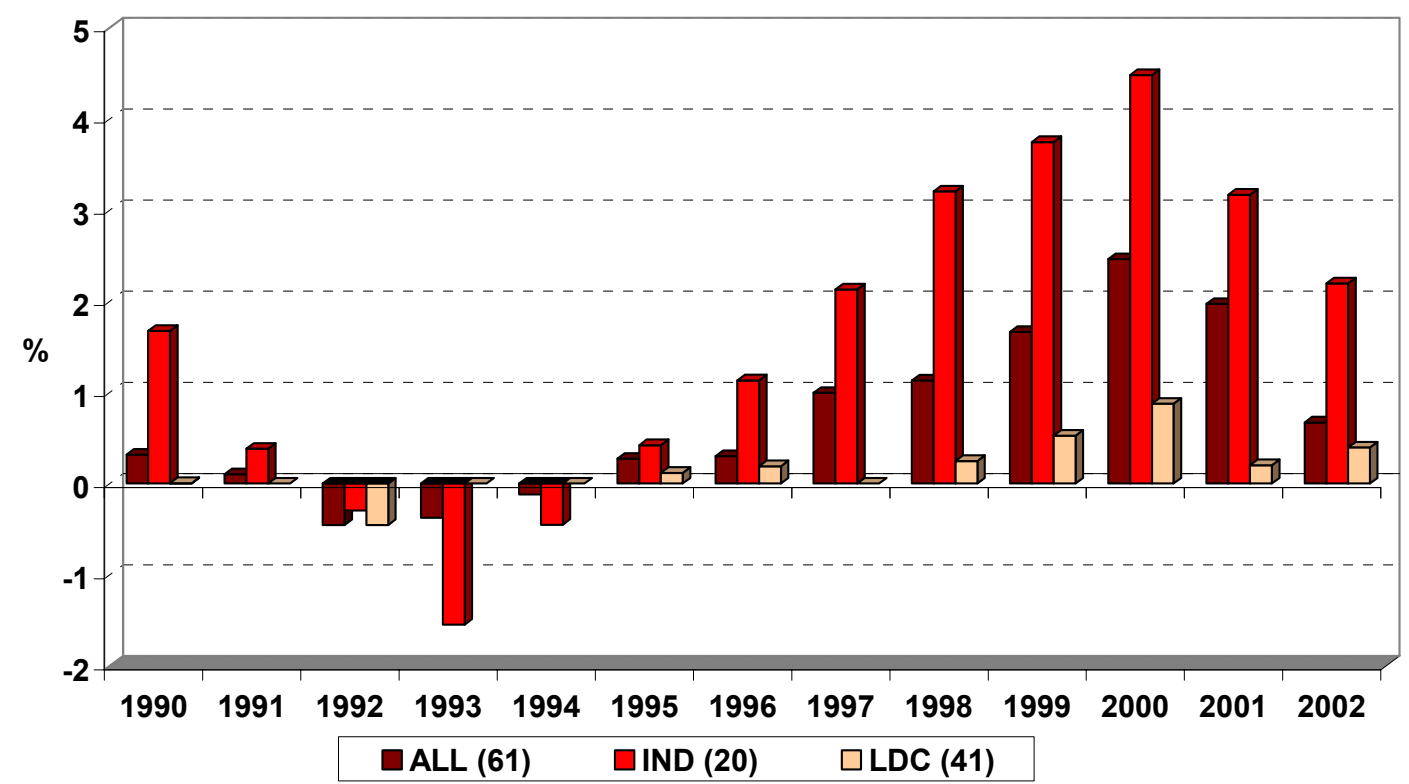

Source: FITCH.

Note: These data differ in source and coverage from those underlying Figure II.6. Therefore the two figures are not strictly comparable.

It is more difficult to gauge monetary stability, given the diversity of monetary arrangements across developing countries and over time. One rough measure is the resort to seigniorage -- i.e., money financing of the deficit. Measured by the change in the monetary base relative to GDP, seigniorage collection showed a rising trend in the late 1980s and early 1990s and then declined in both middle-income and (more modestly) low-income economies, a pattern roughly similar to that of the inflation rate shown above. (Figure II.8). 
Figure II.8: Developing Countries: Seigniorage Revenues, 1966-2001 (percent of GDP, medians by country income group)

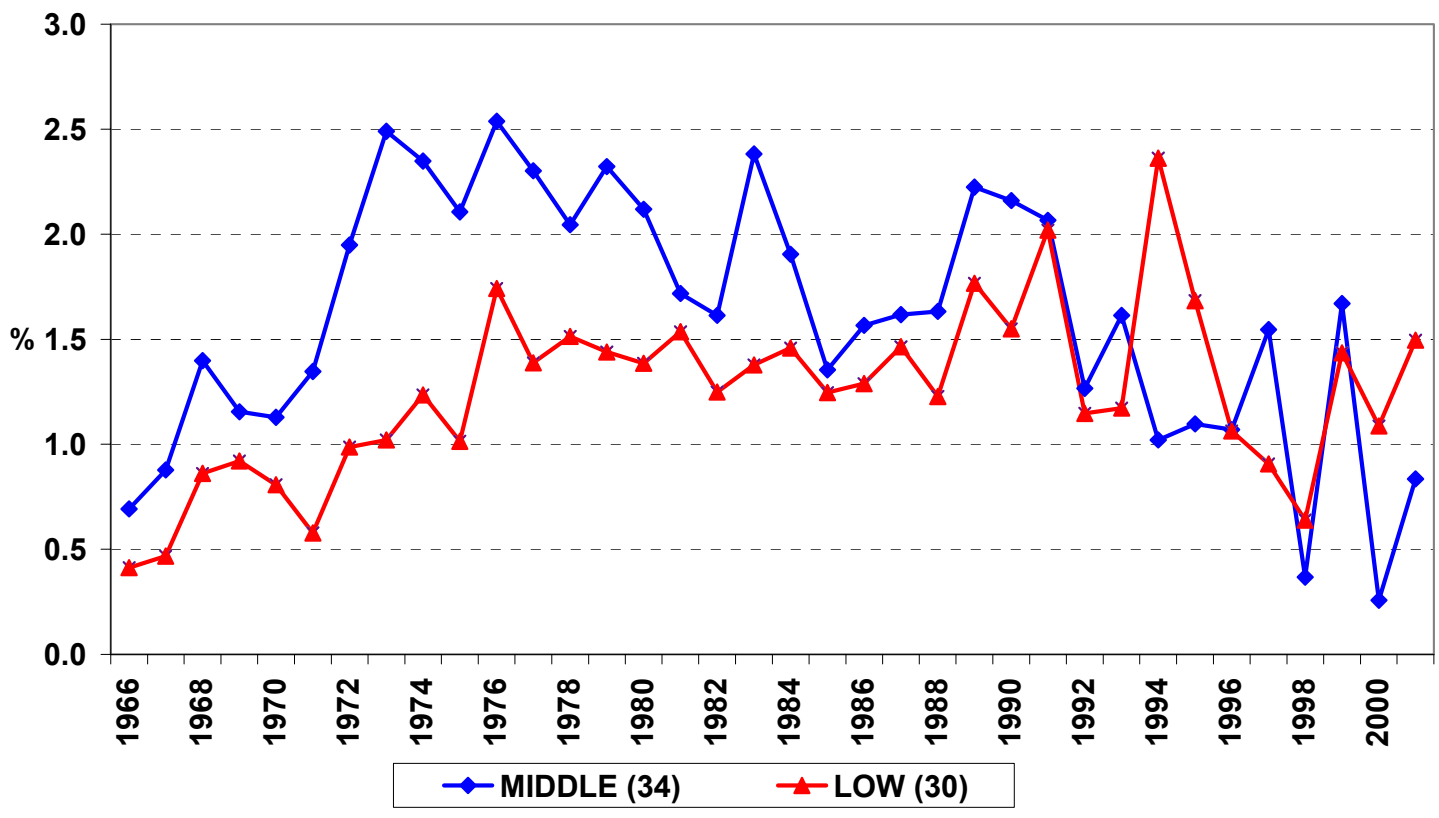

Sources: IMF-IFS and WDI-WB.

Note: The countries featured are those for which data are available over the entire period shown.

The diversity of exchange rate arrangements across countries also makes it hard to gauge exchange rate policy. One indirect approach looks at the trends in real exchange rates. $^{14}$ The evidence (Shvets, 2004) shows that real exchange rates depreciated over the $1990 \mathrm{~s}$ in a majority of developing economies. In turn, real exchange rate volatility ${ }^{15}$ showed a decline from the record-highs of the 1980s. But the decline was limited to middle-income countries, and over the 1990s developing countries as a group continued to exhibit much higher real exchange rate volatility than industrial countries (Figure II.9).

\footnotetext{
${ }^{14}$ These are of course endogenous and subject to the influence of a variety of factors. While the nominal exchange rate is only one of such factors, it is arguably an important one.

${ }^{15}$ Measured by the standard deviation of its rate of change.
} 
Figure II.9: Real Exchange Rate Volatility, 1961-2000

(percent, medians by income group)

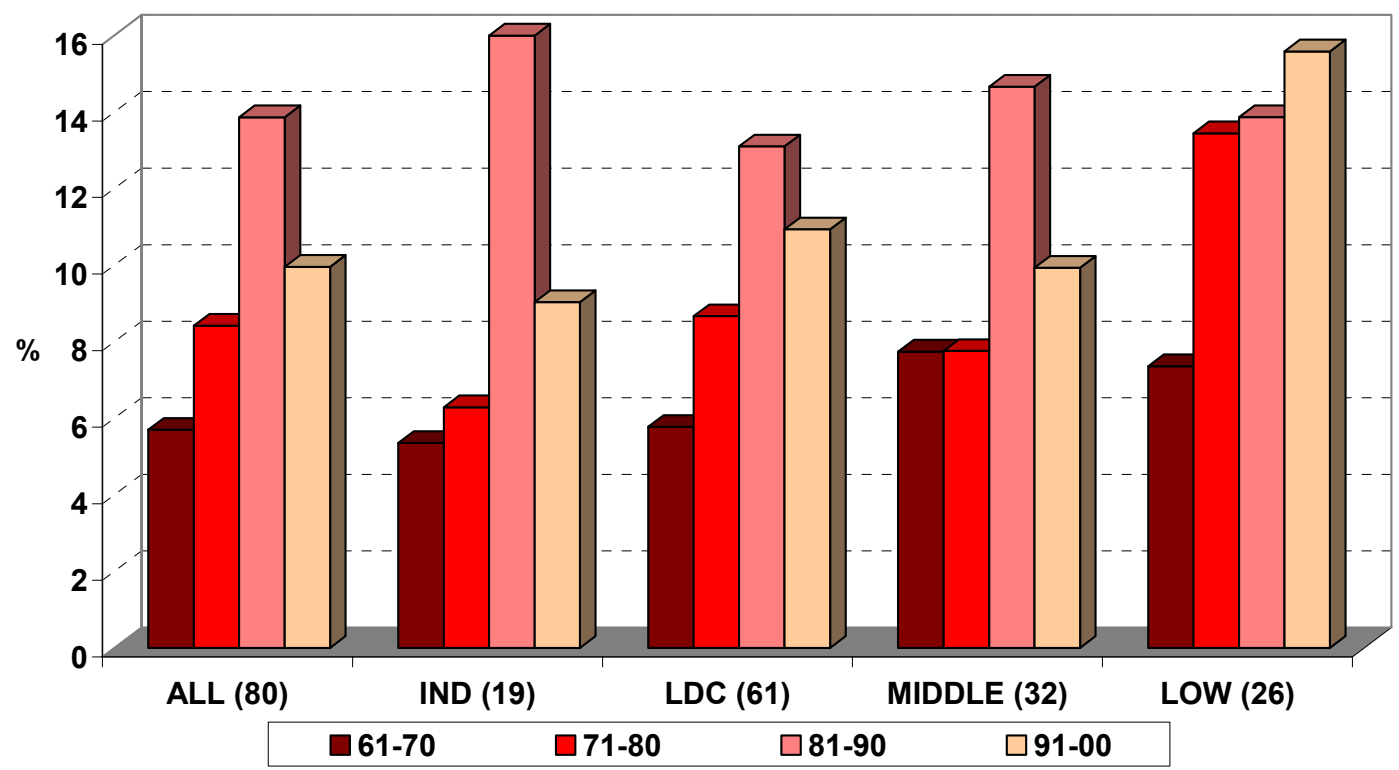

Source: WPENN Table.

Note: Figure shows the standard deviation of the rate of change in the real exchange rate. The countries featured are those for which data are available over the entire period shown.

This high volatility of the real exchange rate was in part a reflection of the high incidence of exchange-rate crashes in the decade, when, as Figure II.10 shows, large devaluations were a frequent phenomenon. Their incidence peaked in 1994 (with the devaluation of the CFA Franc) and 1998 (with the East Asia and Russia crises). Taking the decade as a whole, exchange rate crashes were slightly less frequent in the 1990s than in the $1980 \mathrm{~s}$, but much more so than in the $1960 \mathrm{~s}$ and $1970 \mathrm{~s} .{ }^{16}$ High real exchange-rate volatility and frequent exchange-rate collapses suggest that over the 1990s progress in achieving robust nominal exchange rate arrangements was limited.

\footnotetext{
${ }^{16}$ In a smaller country sample (whose time coverage ends in 1997), Bordo et al (2001) also find that the frequency of currency crashes declined in the 1990s vis-à-vis the preceding 15 years.
} 
Figure II.10: Developing Countries: Exchange Rate Crises, 1963-2002 (relative frequency, percent)

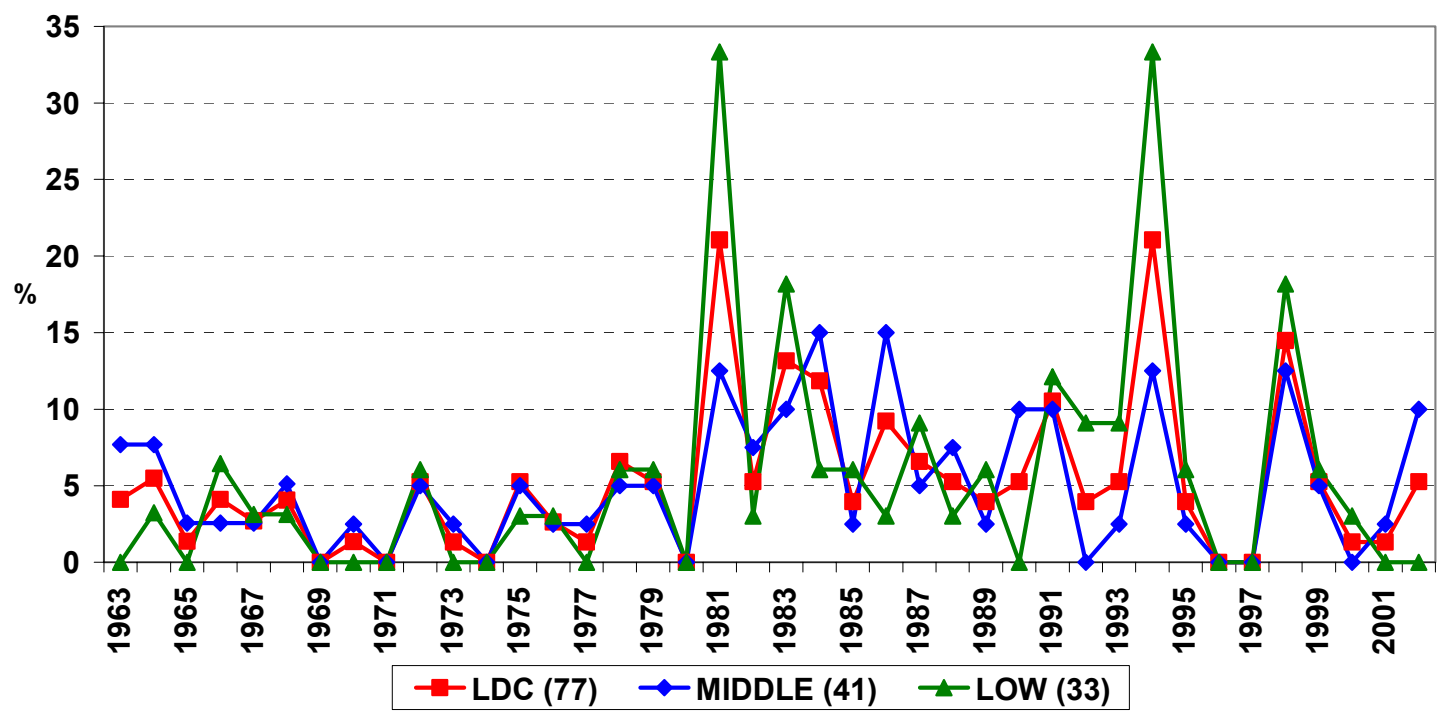

Source: IMF-IFS.

Note: For this figure an exchange rate crisis is defined as in Frankel and Rose (1996): a depreciation of the (average) nominal exchange rate that (a) exceeds 25 percent, (b) exceeds the preceding year's rate of nominal depreciation by at least 10 percent, and (c) is at least three years apart from any previous crisis. The countries featured are those for which data is available over the entire period shown.

\section{II.3 The External Environment}

The final ingredient behind the observed trends in macroeconomic instability is the pattern of external real and financial shocks. Indeed, the rapid propagation (or "contagion") of external financial disturbances is viewed by many observers as an important contributor to the major crises of the 1990s.

Regarding real disturbances, Shvets (2004) has documented the relatively modest magnitude of terms-of-trade shocks affecting developing countries in the 1990s. The volatility of the terms of trade declined in all developing regions, in most cases to levels comparable to those of the 1960s. The only exception was the Middle East and North Africa region, where terms-of-trade volatility was nevertheless below the levels of the 1970s and 1980s.

It is more difficult to assess the volatility of the financial environment. Though the behavior of interest rates in the world's major financial markets captures some of this volatility, the terms on which capital is available to developing countries incorporate risk premia that tend to be much more volatile than industrial-country interest rates. On the other hand, volatility measures based on such premia or on the behavior of capital flows are not necessarily good indicators of the volatility of the international financial environment, since they are partly endogenous to events in the borrowing countries themselves. 
Keeping this caveat in mind, Figure II.11 portrays the volatility of international net capital flows as measured by their standard deviation. Like real volatility captured by the terms of trade, this measure suggests that the volatility of the external financial environment also decreased relative to the 1980s. The decline was modest, however, so that during the 1990 s capital flows to developing countries remained much more volatile than those to industrial countries.

Figure II.11: Volatility of Net Capital Flows, 1977-2000

(percent, medians by country income group)

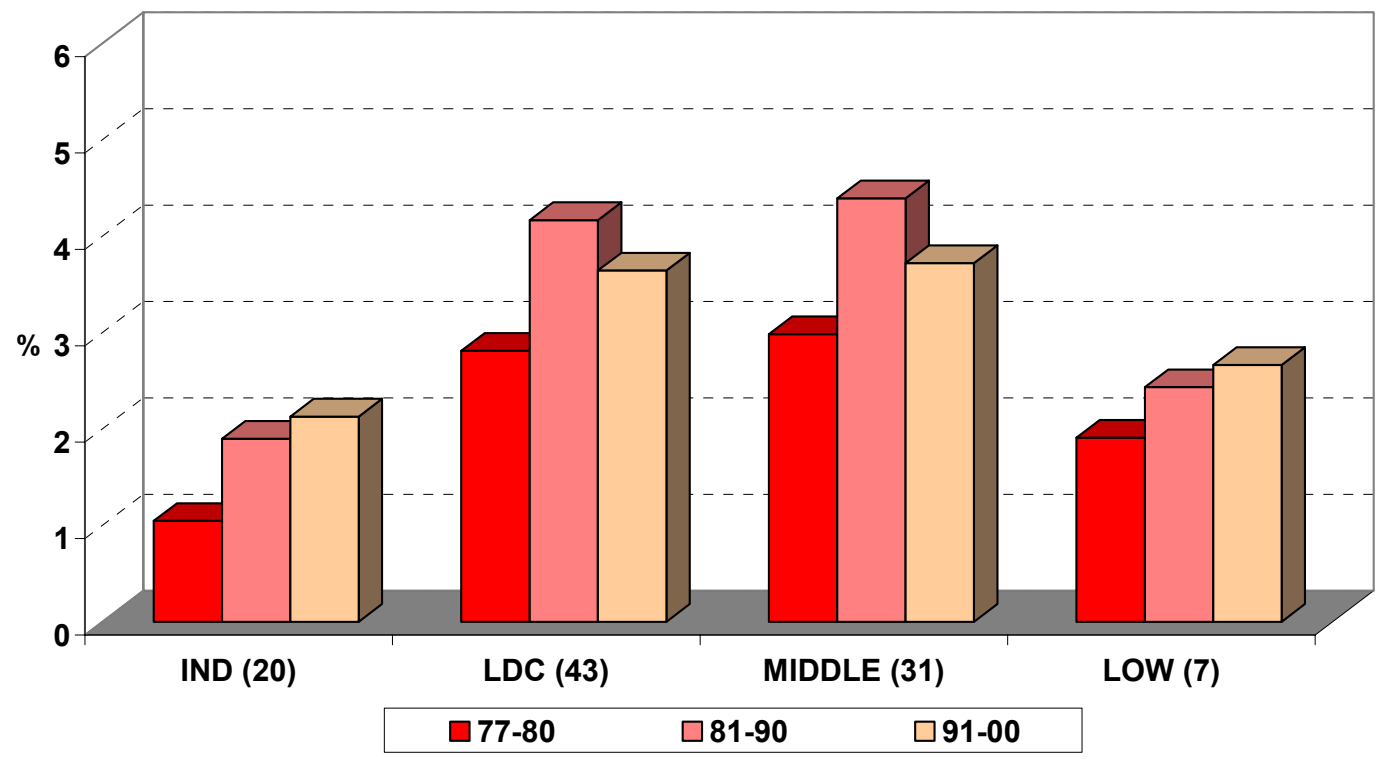

Source: IMF-IFS.

Note: Figure shows the standard deviation of net capital flows as percentage of GDP. Using instead the coefficient of variation leads to qualitatively similar results. The countries featured are those for which data is available over the entire period shown.

A number of observers have pointed out that large capital flow reversals -- often termed "sudden stops" -- can be much more damaging for developing economies than general capital-flow variability, as such abrupt stoppages force costly and disruptive real adjustments. ${ }^{17}$ Figure II.12 offers a perspective on the incidence of such reversals among developing countries during the 1990s. By the measure used here, there was little change relative to the 1980 s in the frequency of sudden stops. Their incidence declined in the first half of the 1990s, but then rose again in the second half, peaking around the time of the East Asia and Russia crises. ${ }^{18}$

\footnotetext{
${ }^{17}$ See Calvo (1998), Calvo and Reinhart (2000) and Mendoza (2001). However, note again that capital flow turnarounds do not necessarily represent exogenous shifts in international investors' sentiment. They reflect in part the effects of developments in the destination economies (resulting, among other factors, from changing domestic policies) as well as in international financial markets affecting the perceived risk and return differentials from investing in different markets.

${ }^{18}$ To keep things in perspective, it should be noted that the incidence of capital flow reversals among industrial countries (not shown to avoid cluttering the graph) was also fairly high in the 1990s -- although admittedly the level of capital flows is much higher among them than among developing countries.
} 
Figure II.12: Developing Countries: Sudden Stops in Net Capital Inflows, 1978, 2000 (relative frequency, percent)

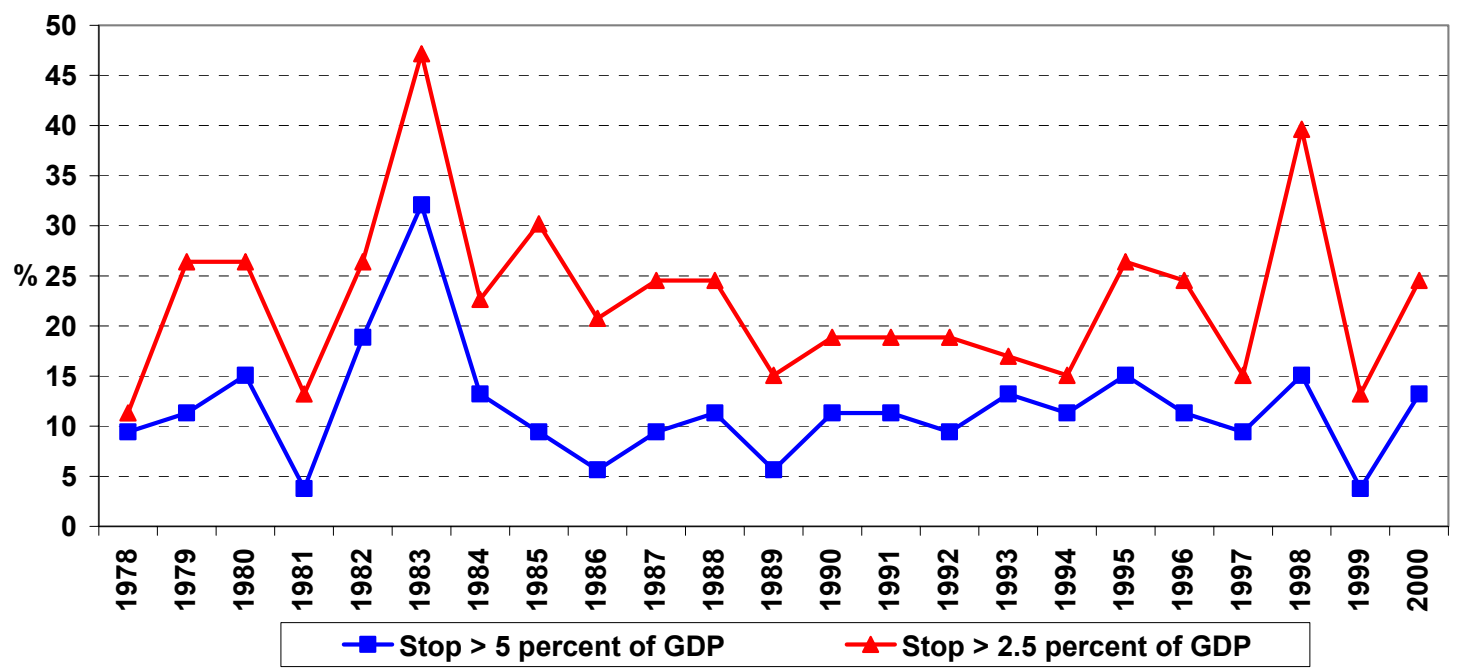

Source: IMF-IFS. Balanced sample includes 53 countries.

Note: Data for the first half of the 1970s are too limited to allow a comprehensive analysis. Sudden stops are defined as declines in net capital inflows in excess of a given percentage of GDP. Reversals are allowed to take place in adjacent years; using instead a 2-year window leads to similar qualitative conclusions. Note that reversals could have been defined instead in terms of (large) changes in the current account deficit (as done, for example, by Hutchison and Noy, 2002). However, when applied to a large cross-country sample such as the one at hand, the latter criterion tends to pick up numerous current account reversals (particularly in low-income countries) primarily due to terms-of-trade shocks in a context of modest changes in capital flows.

\section{II.4 Summary}

Over the 1990s developing countries achieved notable progress on fiscal consolidation and inflation performance. Improved fiscal and nominal stability helped achieve a moderate reduction in output volatility, facilitated also by a somewhat more stable external environment. But the picture is far from rosy. In terms of outcome variables, developing countries remain much more unstable than industrial ones.

Moreover, extreme volatility accounted for a larger share of total volatility in the 1990s than previously. This latter fact is consistent with evidence suggesting that instances of currency crashes and "sudden stops" in capital inflows did not tend to diminish during the 1990s. The picture is therefore one of dramatic policy improvements in some areas, of more moderate improvements in stability of macroeconomic outcomes, and of persistent vulnerability to extreme macroeconomic events. The next section relies on these findings to interpret the growth performance of developing countries during the 1990s.

\section{Assessing the Experience of the 1990s}

The previous section has shown that macroeconomic performance improved along several important dimensions among developing countries during the decade of the 1990s. These improvements were largely driven by the quest for higher growth. Yet as Pritchett (2004a) argued, the growth payoff from these macro performance gains fell short of expectations. Why was this so? To address this question, this section first 
reviews the analytical links between macroeconomic stability and economic growth and then applies that analytical framework to the experience of the 1990s.

\section{III.1 From Stability to Growth}

As already noted, a stable macroeconomic policy environment features a fiscal stance safely consistent with fiscal solvency, a monetary policy stance consistent with a low and stable rate of inflation and a robust exchange-rate regime that avoids both systematic currency misalignment as well as excessive real exchange-rate volatility. Policy stability can foster stability of macroeconomic outcomes both directly -- by removing destabilizing policies themselves as sources of shocks -- as well as indirectly -by allowing policies to be deployed as stabilizing instruments in response to exogenous destabilizing shocks, thus enhancing the stability of key outcome variables. But a stable policy framework is not an end in itself: it matters only for instrumental reasons, as a means to secure a more stable overall macroeconomic environment.

On conceptual grounds, however, the link between policy stability and growth may turn out to be rather complex. In particular:

- The direct contribution that policy stability can make to growth (by not being an additional source of instability) is likely to depend on the institutional setting. In simple terms, what matters is not just whether policy realizations are good today, but the perceived likelihood that good policies will be repeatedly implemented in the future. To have a significant impact on growth, actual gains in macroeconomic stability need to be viewed by the private sector as indicative of a permanent change in the macroeconomic policy regime.

- The potential indirect contribution of policy stability to growth -- by promoting outcomes stability -- is likely to depend on the economy's degree of macroeconomic fragility -- i.e., the extent to which even relatively minor shocks can have large effects on the economy. On the one hand, fragility may make it too costly to deploy stabilization policies for fear of potentially adverse effects. The result is policy paralysis. On the other hand, fragility can mean that the instability that policy has to counter may become so severe that feasible policy adjustments are unable to counter it.

These two points suggest that the type of macroeconomic stability likely to be most conducive to economic growth -- durable outcomes-based stability -involves much more than just moving fiscal, monetary and exchange-rate policies in stabilizing directions. It also requires that policy-based stability be given a solid institutional underpinning, that sources of macroeconomic fragility be eliminated to the greatest possible extent and that the authorities actively exploit the scope for stabilization policy created by these two improvements in the macroeconomic environment.

- Finally, as already stressed, growth does not depend only on macroeconomic stability. In other words, the effectiveness of outcomes stability itself in 
promoting economic growth is likely to depend on a variety of growth determinants, including microeconomic factors.

The next section evaluates the reform agenda of the 1990s from this analytical perspective.

\section{III.2 How Much Progress Was Really Achieved in the 1990s?}

On the whole, as shown in Section II, there were significant achievements in terms of stability in the traditional macroeconomic policy sense during the late 1980s and early 1990s. But these achievements were not universal; they were not always grounded on solid institutional foundations to guarantee their permanence; and they frequently did not translate into a more effective use of macro policies as stabilization instruments.

A useful framework within which to organize discussion of these issues is the public sector solvency condition that requires the present value (PV) of primary surpluses and seigniorage revenue to be at least as large as the government's outstanding stock of net debt, i.e.:

$$
\mathrm{PV}(T-G+\mathrm{d} M) \geq B(0)
$$

From the viewpoint of macroeconomic policies, stability requires that the authorities set the monetary and fiscal policy stance consistently with maintaining the public sector's solvency at low levels of inflation, while leaving at the same time some scope for mitigating the impact of real and financial shocks on macroeconomic performance. Obviously, the former requirement imposes constraints on the magnitudes of both the primary deficit $(G-T)$ and its money financing $\mathrm{d} M$, while the latter refers to the profiles of monetary and fiscal policy over the business cycle.

Most importantly, these requirements apply not only to current policies, but also to future ones, as implied by the present value term in the expression. Indeed, one of the key dilemmas for macroeconomic policy-making is precisely how to achieve and convey to the private sector the assurance that future policies will abide by the requirements of solvency and low inflation -- without having to surrender the short-run stabilization capability of monetary and fiscal policy. As will be discussed later, many of the achievements and disappointments of the 1990s relate to the search for lasting solutions to this dilemma. But first, reassessing developments during the 1990s in the light of the above expression, the following key observations emerge:

\section{i. A comfortable perception of fiscal solvency remains to be established in most countries.}

In spite of the trend toward lower fiscal deficits documented in Section II, public debt ratios remained high in most developing countries, and in general they showed little tendency to decline during the 1990s. Among the set of developing countries for which data are available, the median public debt/GDP ratio remained in the 50-60 percent range over the decade (Figure III.1). An incipient decline through 1997 was followed by a 
rising pattern after that date, so that by 2001-02 the median developing-country debt ratio exceeded the 1990-01 level -- as did the median industrial-country debt ratio. ${ }^{19}$ The rising trend was particularly marked among low-income countries, although data availability is too limited to draw firm conclusions. ${ }^{20}$ On the whole, for the 46 low- and middle-income countries in the sample underlying Figure III.1, debt/GDP ratios rose in 24 and fell in 22.

Figure III.1: Government Debt, 1990-2002

(percent of GDP, medians by country income group)

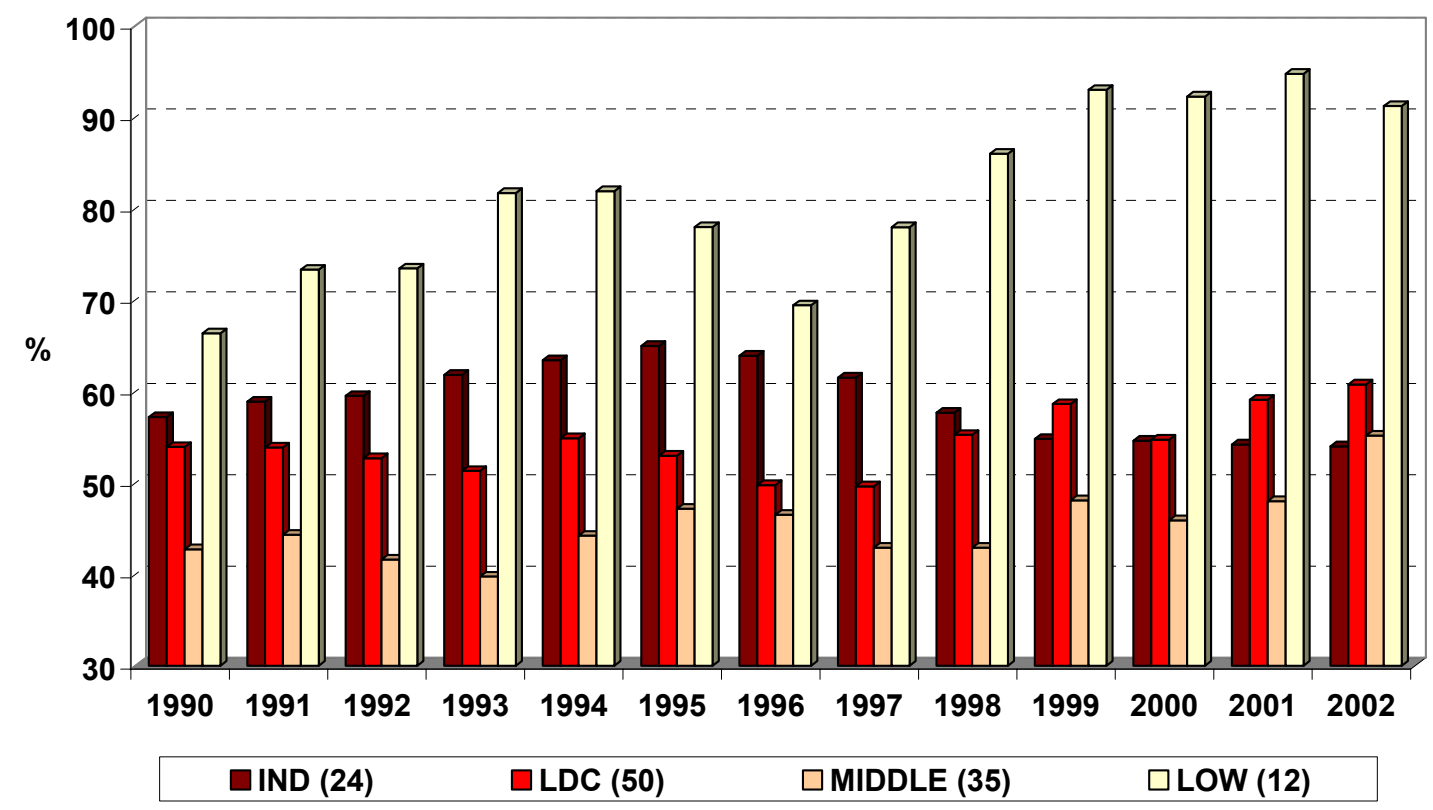

Sources: WDI-WB, WEO-IMF and FITCH.

This persistence of high debt over the 1990s -- and its upward drift at the end of the decade -- reflects a number of factors. First, improvements in fiscal performance were not universal. In India, for example, continuing large primary deficits (averaging close to 4 percent of GDP in the late 1990s) were the main factor behind persistent high debt ratios. More generally, fiscal vulnerabilities played a prominent role in some of the major financial crises of recent years -- Russia in 1998, Ecuador in 1999, and Argentina in $2002 .^{21}$

\footnotetext{
${ }^{19}$ The same pattern is found in IMF (2003a).

${ }^{20}$ It should be noted that debt/ GDP ratios do not accurately reflect the debt burdens faced by low-income developing countries relative to the other groups in Figure III.1, since the latter tend to have a large share of debt in concessional terms. The focus here, however, is on changes in levels of debt over time within each group of countries.

${ }^{21}$ For example, in Argentina the expansionary fiscal stance followed in the 1995-97 boom left the authorities virtually no room to adjust to the global real and financial slowdown after the Russian crisis of 1998 and to the real appreciation of the peso under the hard dollar peg; see Perry and Servén (2003). On the Russian case, see Kharas and Pinto (2001). For Ecuador, see Montiel (2002).
} 
In many cases, the pressure of weak public finances on debt accumulation was brought into the open by an attempt at rapid disinflation, which implied a drop in deficit monetization (as reflected by the decline in seigniorage revenues documented in section II). In the absence of an equally rapid correction of the primary deficit, debt issuance was left as the only available source of financing. The debt impact of disinflation is confirmed by the empirical fact that over the 1990s disinflation is associated with subsequent rises in debt ratios, and the association is statistically significant.

But in a majority of developing countries primary deficits did decline over the 1990s (as shown in Section II), and other factors accounted for the lion's share of public debt accumulation. Key among these was the cost of banking-system bailouts, which was the main ingredient behind the increasing public-sector debt burden in a number of instances. ${ }^{22}$ As Figure III.2 shows, some of the banking crises of the $1990 \mathrm{~s}$-- especially those of East Asia in 1997 -- ranked at the top of the historical record in terms of their fiscal impact. ${ }^{23}$ Through this and other channels, involving implicit net transfers from poorer households to financial system participants in order to rescue and recapitalize the failed banks, such crises had adverse effects also on income distribution. ${ }^{24}$

\footnotetext{
${ }^{22}$ Beyond banking system bailouts, realization of other contingent liabilities, as well as recognition of hidden ones, was also a significant source of debt accumulation in some countries. Argentina is a good example; see Mussa (2002).

${ }^{23}$ However, Bordo et al (2001) find that the output cost of banking crises did not show any significant increase over the 1990s.

${ }^{24}$ See Halac and Schmukler (2003) for a detailed discussion.
} 
Figure III.2: Total Fiscal Costs of Systemic Banking Crises as a percent of GDP

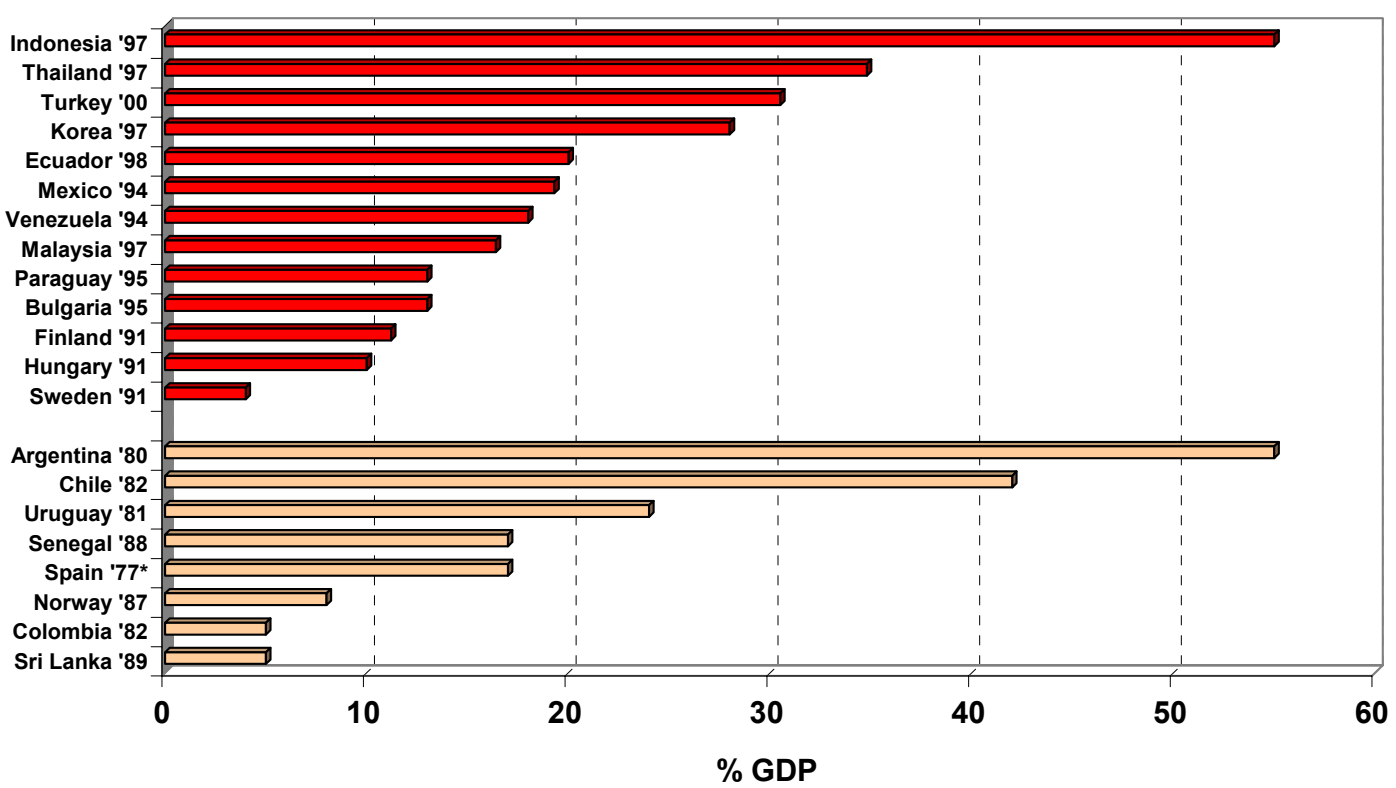

Source: Caprio and Klingebiel (2003). Note: $\left(^{*}\right)$ percent of GNP.

Large real exchange-rate depreciations, in a context in which the bulk of public debt is denominated in (or indexed to) foreign currency, were another major factor behind the upward trend in debt stocks in the late 1990s. In Argentina and Uruguay, for example, the exchange-rate collapse of 2002 more than doubled the debt/GDP ratio -- from 50 to over 140 percent of GDP in Argentina and from 40 to over 80 percent in Uruguay. The predominance of foreign-currency-denominated debt in many countries reflects the weakness of domestic-currency debt markets, and in some cases also a myopic debt management strategy that selects the denomination of debt issuance on the basis of interest costs alone, neglecting both exchange-rate and interest-rate risk (see below). Across emerging markets, debt dollarization remained pervasive: the median ratio of foreign-currency debt to total public debt rose over the late 1990s to exceed 55 percent by 2001 (Figure III.3). 
Figure III.3: Developing Countries' Foreign Currency Debt, 1997 and 2001

(percent of general government debt, medians by country income group)

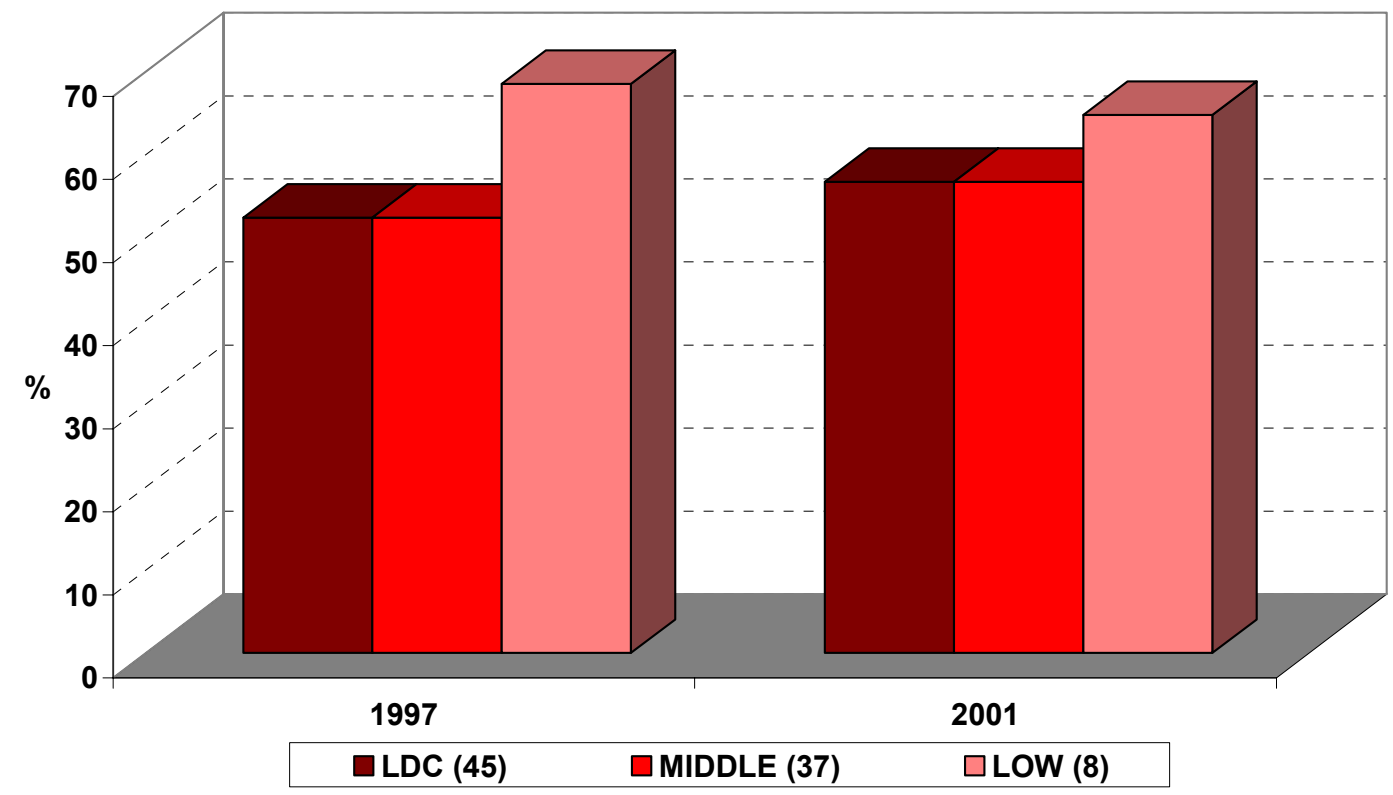

Source: Moodys.

A third ingredient behind the persistence of high debt was the high level of real interest rates in many countries, particularly in the late 1990s, largely reflecting the lack of credibility in their stabilization efforts-documented below. Again, myopic debt management involving excessive reliance on short-maturity debt made some countries' overall fiscal outcomes -- and thus their rates of public debt accumulation -- highly sensitive to changes in domestic interest rates. Thus, in some countries (notably Brazil) high real interest rates contributed to a rapid pileup of public debt that further weakened perceptions of solvency and macroeconomic stability.

In terms of the solvency constraint introduced earlier, the bottom line is that, through all these channels, increases in the observed value of the primary surplus $T-G$ did not suffice in many countries to bring down the burden of public debt and establish a comfortable perception of fiscal solvency.

A strong indication that solvency perceptions remained shaky in the 1990s is the fact that default risk premia, as measured by sovereign borrowing spreads in international markets, remained highly volatile for most emerging countries over the decade (Figure III.4). The evidence suggests that default risk depends not only on debt burdens, but also on investors' perceptions about the quality of borrowers' policy and institutional framework. ${ }^{25}$ Thus, the volatility of risk premia likely reflected -- among other factors -the market's lack of confidence in borrowers' commitment to stability.

\footnotetext{
${ }^{25}$ See Kraay and Nehru (2003). The fact that weak policies and institutions (or other factors) can result in high default risk even at moderate levels of debt has prompted recommendations for extra-cautious upper bounds on debt ratios for developing economies; see Reinhart, Rogoff and Savastano (2003). On the other
} 
Figure III.4: Emerging Markets Bond Index for Latin and Non-Latin Borrowers

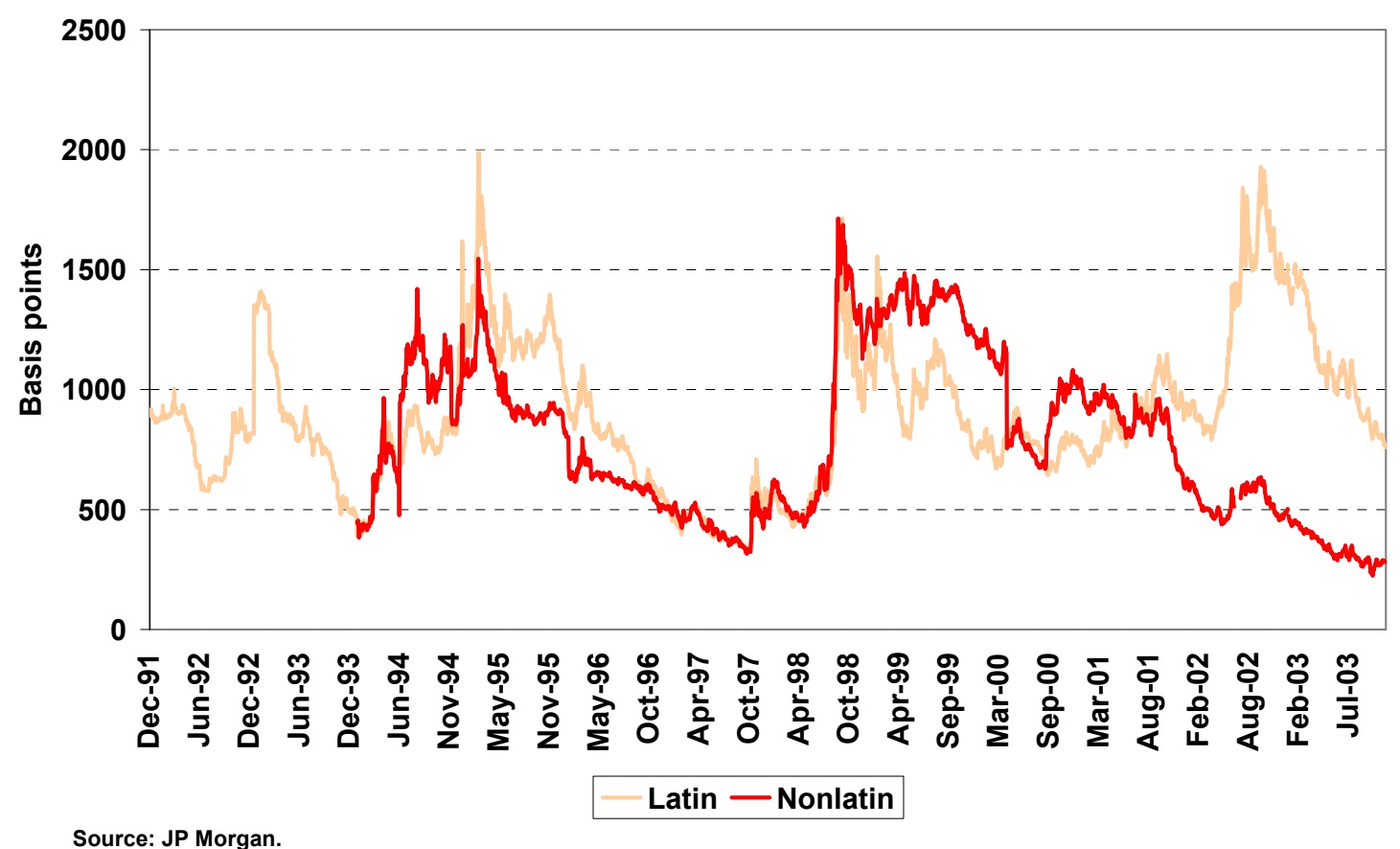

But perceptions of high default risk are not just a symptom of perceived vulnerability. They also contribute to undermining the achievement of durable outcomesbased macroeconomic stability indirectly. In particular, they hamper countries' ability to conduct stabilizing policy: when default is perceived to be high and highly sensitive to changes in circumstances, attempts to run deficits at times of cyclical contraction may be viewed with suspicion and result in large jumps in risk premia (and thus borrowing costs), thus discouraging the use of countercyclical fiscal policy. ${ }^{26}$ Moreover, the scope for independent monetary policy can also be severely constrained by the impact of changes in monetary stance on the cost of public debt through the associated changes in the nominal exchange rate and interest rates.

\section{ii. Improvement in fiscal balances has often been achieved either with stopgap measures} unlikely to be sustainable, or in ways inimical to growth and welfare.

But weaknesses in fiscal adjustment were not limited to the fact that increases in debt often offset improvements in primary surpluses. In numerous instances, those improvements themselves were likely to be perceived as purely temporary -- either because the measures generating them were transparently transitory in nature, or because they directly compromised future growth and welfare. In terms of the solvency constraint

hand, the dependence of spreads on lenders' expectations raises the possibility of self-fulfilling debt crises (see e.g., Cohen and Portes, 2004).

${ }^{26}$ This is empirically confirmed by Calderón, Duncan and Schmidt-Hebbel (2003). 
above, such adjustments often did impact significantly on the current deficit but had little effect (or even an adverse one) on the path of future deficits.

Such temporary fiscal correction was sometimes achieved by resorting to a variety of fiscal tricks designed to meet short-term deficit or debt targets without making any substantive progress toward fiscal solvency. A common device involves changes in the timing of expenditures (e.g., postponing them into subsequent fiscal years or accumulating payments arrears) and/or revenues (e.g., speeding up the extraction of exhaustible resources or advancing tax collection) without altering their present value, which is the relevant magnitude for solvency. Another popular strategy involves onetime asset sales to finance the retirement of public debt, which in principle implies no change in the government's net worth. Likewise, governments have often resorted to replacing explicit debt with contingent liabilities (e.g., granting debt guarantees rather than subsidies to public firms). All these measures share a common feature: they lead to improvements in conventional cash deficit and gross debt indicators -- the two fiscal benchmarks closely watched by investors and IFIs -- but have no effect on solvency. In other words, they represent illusory fiscal adjustment. ${ }^{27}$

In other instances, the appearance of fiscal adjustment may reflect a rise in revenues resulting from a temporary boom in tax bases -- for example, a consumption boom fueled by a transitory surge in capital inflows in an economy with a VATdominated tax system. When the boom comes to an abrupt end, a major fiscal gap opens in the recession. There is evidence that this mechanism played a significant role in some emerging markets in the 1990s (Talvi, 1997).

More generally, in many fiscal-adjustment episodes the focus on the quantity of adjustment was not matched by a comparable emphasis on its quality. The attention given to public spending composition and to its implications for growth and welfare has often been very limited. This disinterest sometimes resulted in achieving adjustment at the cost of leaving critical social needs unmet, e.g., by giving inadequate protection to critical social expenditures (IMF 2003b, chapter 6).

More often than not, productive public expenditures (on items such as human capital formation and infrastructure) have also been compressed in the process of fiscal adjustment. The main reason is that the emphasis on cash deficits and debt discourages projects whose costs are borne upfront but whose returns accrue only over time. Such projects have the same impact on the government's short-term financing needs as pure consumption or any other spending item even though their impact on solvency is quite different because, unlike consumption, they involve creating assets that yield future revenues - be it directly, or in the form of augmented tax collection through higher output. Conventional fiscal aggregates (such as the primary or the overall surplus) closely monitored by IFIs and investors ignore this distinction, and the result is that fiscal adjustment tends to have an anti-investment bias amply documented in both industrial

\footnotetext{
${ }^{27}$ Easterly (1999) offers a variety of examples. These tricks are not exclusively used by developing countries. Many industrial countries have engaged in similar practices, particularly in the run-up to EMU. See also Easterly and Servén (2003).
} 
and developing countries. ${ }^{28}$ To the extent that reduced investment lowers growth and hence future tax bases, such bias can have adverse consequences for growth -- even for fiscal solvency itself. The experience of Latin America, where declining public infrastructure spending accounted for the bulk of the fiscal correction achieved by some of the region's major countries in the 1990s, provides a good example of this perverse dynamics.

\section{iii. In many countries, fiscal policy remains destabilizing}

As already noted, the stabilizing power of fiscal policy depends largely on its ability to mitigate cyclical fluctuations. But in developing countries fiscal policy tends to behave in a pro-cyclical manner, expanding in booms and contracting in recessions, a pattern that makes it a major source of macroeconomic instability.

Take for example the cyclical behavior of public consumption. Empirical estimates show that, on average, a 1-percent increase in GDP growth tends to raise the growth rate of public consumption spending by around 0.5 percentage points in developing countries. The corresponding figure for industrial countries is much smaller (around 0.15 ), and for the largest of them (the G-7 countries) the response of public consumption is actually negative. ${ }^{29}$ Figure III.5 shows that, by this measure, fiscal procyclicality among developing countries peaked in the 1980s and declined somewhat over the 1990s -- but still remains much higher than in more advanced countries. Indeed, procyclical fiscal policy played a key role in some of the major crises of recent years, Argentina being a prime example. ${ }^{30}$

\footnotetext{
${ }^{28}$ See Buiter (1990, chapter 5), Easterly and Servén (2003) and Blanchard and Giavazzi (2003). A recent review of fiscal adjustment episodes (IMF 2003b) also concludes that in many cases the cuts in public investment were based on overoptimistic private investment forecasts and turned out to be excessive. ${ }^{29}$ These estimates are reported Talvi and Vegh (2000) and Lane (2003). They are broadly consistent with those displayed in the figure. Public consumption is used rather than the primary deficit because it is available for a much larger sample.

${ }^{30}$ The expansionary fiscal stance adopted by the Argentine authorities during the boom of 1995-97 forced them to engage in a self-destructive contraction in the downswing, helping precipitate the macroeconomic collapse of 2001-2002. See e.g., Mussa (2002) and Perry and Servén (2003).
} 
Figure III.5: Procyclicality of Public Consumption, 1980-2000

(rolling 15-year windows, medians by country income group)

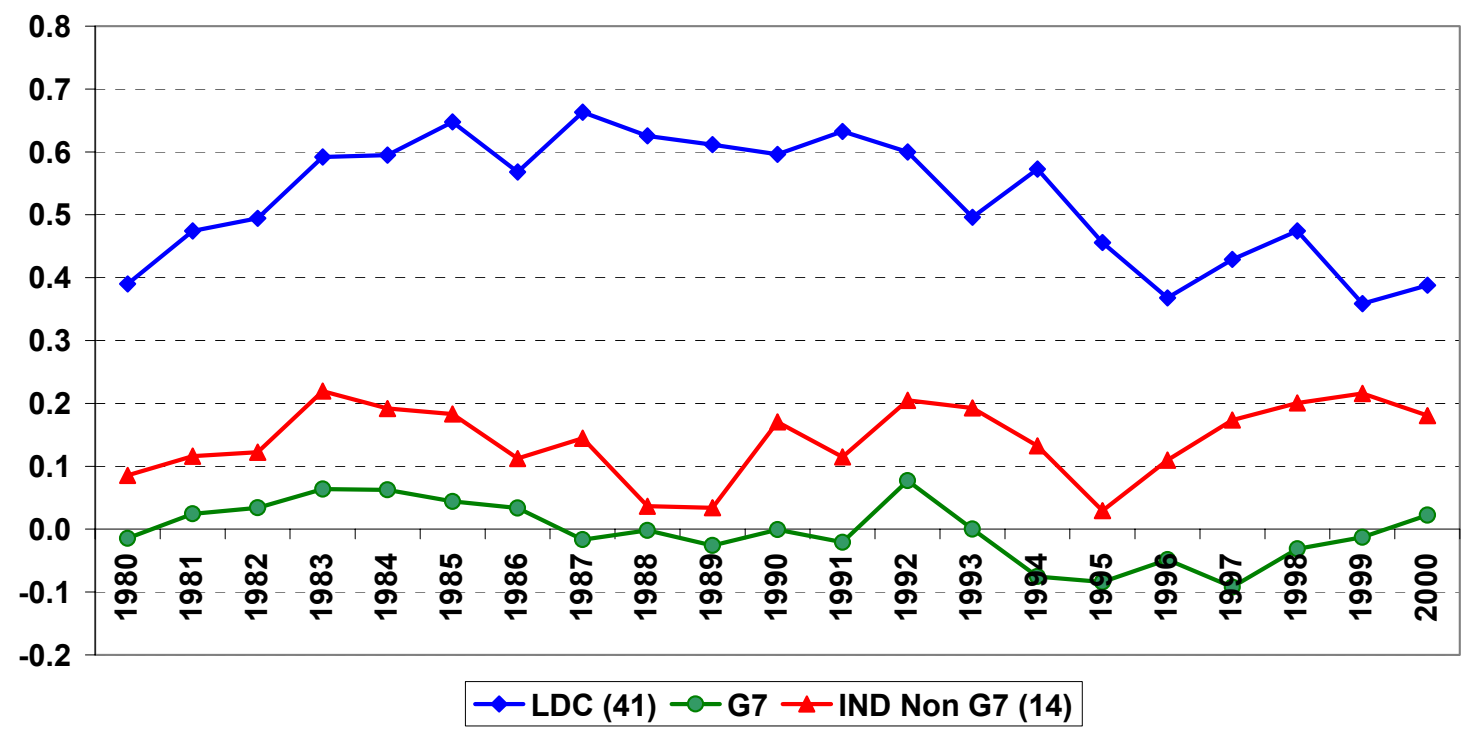

Source: WDI-WB.

Note: The table shows the median of country-specific coefficient estimates obtained regressing the rate of growth of public consumption on the rate of GDP (plus a constant).

\section{iv. Lasting nominal stability remains to be credibly established}

The preceding points refer to two of the three components of the public-sector solvency condition: net debt $B$, and the present value of the primary surplus PV $(T-G)$. The third component is the present value of seigniorage revenue $\operatorname{PV}(\mathrm{d} M)$. As shown in Section II, the 1990s witnessed substantial reductions in deficit monetization among developing countries. But the sustainability of price stability in many of them remains to be established. The key point is that, as the government's intertemporal budget constraint indicates, the roots of inflation are ultimately fiscal. Thus, while a transitory reduction in $\mathrm{d} M$ can be achieved in a variety of ways, unless durable increases in $(T-G)$ are somehow institutionalized, continuing pressures on the government budget will result in debt accumulation that will in turn create pressures for monetization.

Indeed, in many countries reductions in $\mathrm{d} M$ were not accompanied by lasting solutions to fiscal problems. In some cases (e.g., Argentina, Brazil, Ecuador, Mexico, Russia, and Turkey) reduced inflation rates were achieved through exchange rate-based stabilizations. While the improvements in price performance made reductions in moneygrowth rates possible in these cases, the sustainability of this achievement was questionable in all of them. Continued fiscal pressures were accompanied by real exchange-rate appreciations and increases in real interest rates in most of these cases, leading to a pileup of public debt and calling the sustainability of the stabilizations into question. In the cases of Argentina and Ecuador, the inability to enforce fiscal discipline led to the adoption of "hard" exchange rate pegs (a currency board in Argentina and 
dollarization in Ecuador) in the hope that they would somehow result in a hardening of government budget constraints too. Their failure to do so shows that such quick fixes do not suffice to achieve lasting nominal stability in the absence of an independent commitment to responsible fiscal policies. In this way, in Brazil, Mexico and Turkey, exchange rate-based stabilizations relying on "soft" pegs eventually resulted in currency crises that gave way to short bursts of accelerated inflation. Likewise, the devaluation of the CFA franc largely reflected the failure of the CFA arrangements to enforce fiscal discipline in the face of adverse terms of trade shocks.

In the search for nominal stability, some countries adopted in the 1990s an alternative institutional arrangement, which relies on an independent domestic central bank with a commitment to price stability. Like a fixed nominal exchange rate, such an arrangement works in principle by committing the central bank to a low value of $\mathrm{d} M$, thereby imposing a hard budget constraint on the fiscal authorities and forcing the latter to adjust $(T-G)$ to the requirements of price stability. But for such an arrangement to be effective in promoting lasting price stability, the central bank has not only to be committed to price stability, but also to be able to effectively resist pressures for monetization arising from the fiscal side -- i.e., it has to avoid fiscal dominance and achieve true independence from the finance ministry.

How did central bank independence fare among developing countries in the 1990s? Some observers have noted that a good indicator of de facto (as opposed to de jure) central bank independence is the frequency of turnover of the central bank governor. ${ }^{31}$ Figure III.6 provides data on such turnover among developing countries during the 1990s, showing a sharp decrease among middle-income countries relative to the decade of the eighties, and a more modest one among low-income developing countries.

\footnotetext{
${ }^{31}$ Most empirical studies conclude that legal central bank independence is not significantly associated with lower inflation across developing countries (Cukierman, Webb and Neyapti, 1992; Campillo and Miron, 1997). The likely reason is that there are substantial deviations between the letter of the law and its application. As an exception, however, Cukierman, Miller and Neyapti (2001) find a significant negative effect of legal central bank independence on inflation in transition economies with a sufficiently high degree of economic liberalization. A recent study by Gutiérrez (2003) suggests that constitutional sanction of the independence of the central bank, as well as a clear primacy of inflation among its stated objectives, may provide a better measure of its anti-inflationary effectiveness.
} 
Figure III.6: Central Bank Independence in Developing Countries (governor turnover, medians by country income group)

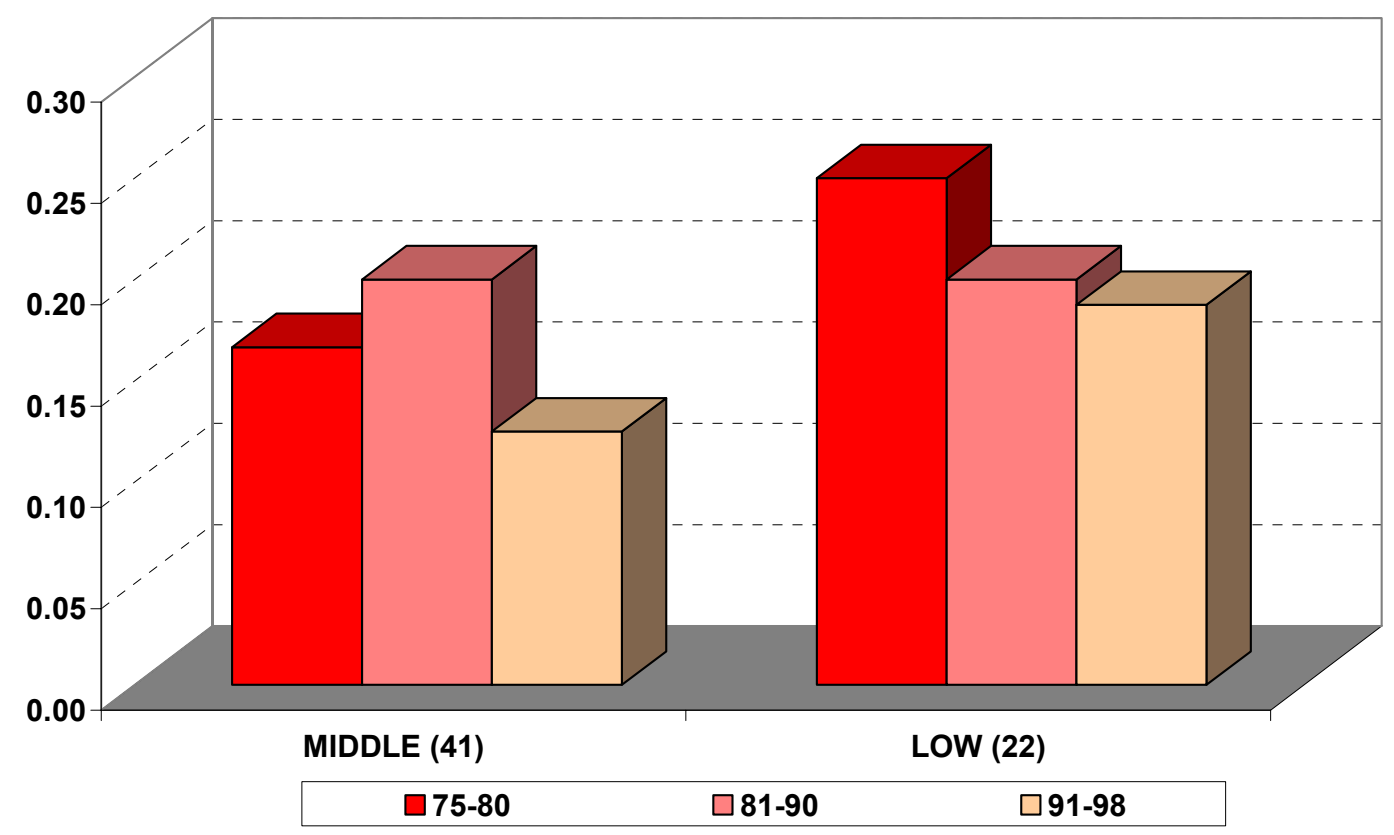

Source: Sturm and de Haan (2001).

However, the rate of turnover of the central bank governor may be a very poor indicator of the expected permanence of nominal stability. ${ }^{32}$ Thus, it may be useful to try to infer the private sector's expectations regarding nominal stability in other ways, at least indirectly, by observing its behavior. One indicator of the confidence that private agents in developing countries may have in the permanence of nominal stability is the incidence of dollarization. Since agents can partly protect themselves against nominal instability by denominating their assets in foreign exchange, improved confidence in nominal stability should result in a reduced incidence of dollarization. ${ }^{33}$ However, many developing countries remained heavily dollarized by the end of the 1990s and, as Figure III.7 shows, the median degree of dollarization of bank deposits among low and middleincome developing countries actually rose over the 1990s. ${ }^{34}$ The contrast with richer

\footnotetext{
${ }^{32}$ Long-serving central bank governors may be subservient to finance ministers who place a high premium on the financing of fiscal deficits, and even independent central bank governors need not be firmly committed to price stability. Indeed, the cross-country empirical association between central bank governor turnover and inflation performance is not robust: the relation is negative only when a few highinflation observations are included in the samples; see de Haan and Koi (2000). This might reflect reverse causality from high inflation to turnover rather than the other way around.

${ }^{33}$ However, perceptions of nominal instability are not the only factor behind financial dollarization. The degree of real dollarization and the perceived stability of the real exchange rate also matter, as do financial system regulations and the availability of other assets sheltering investors from nominal instability (such as instruments indexed to domestic inflation, as in Chile, or short-term interest rates, as in Brazil). For discussion, see de la Torre and Schmukler (2003), Ize and Levy-Yeyati (1998) and IMF (2002a). Thus the interpretation in the text should be taken as suggestive rather than conclusive.

${ }^{34}$ On the trends in dollarization see also IMF (2002) and Reinhart, Rogoff and Savastano (2003).
} 
countries is stark -- their much lower degree of deposit dollarization showed little change over the same period.

Figure III.7: Deposit Dollarization, 1996 and 2001

(foreign currency deposits as percent of total, medians by country income group)

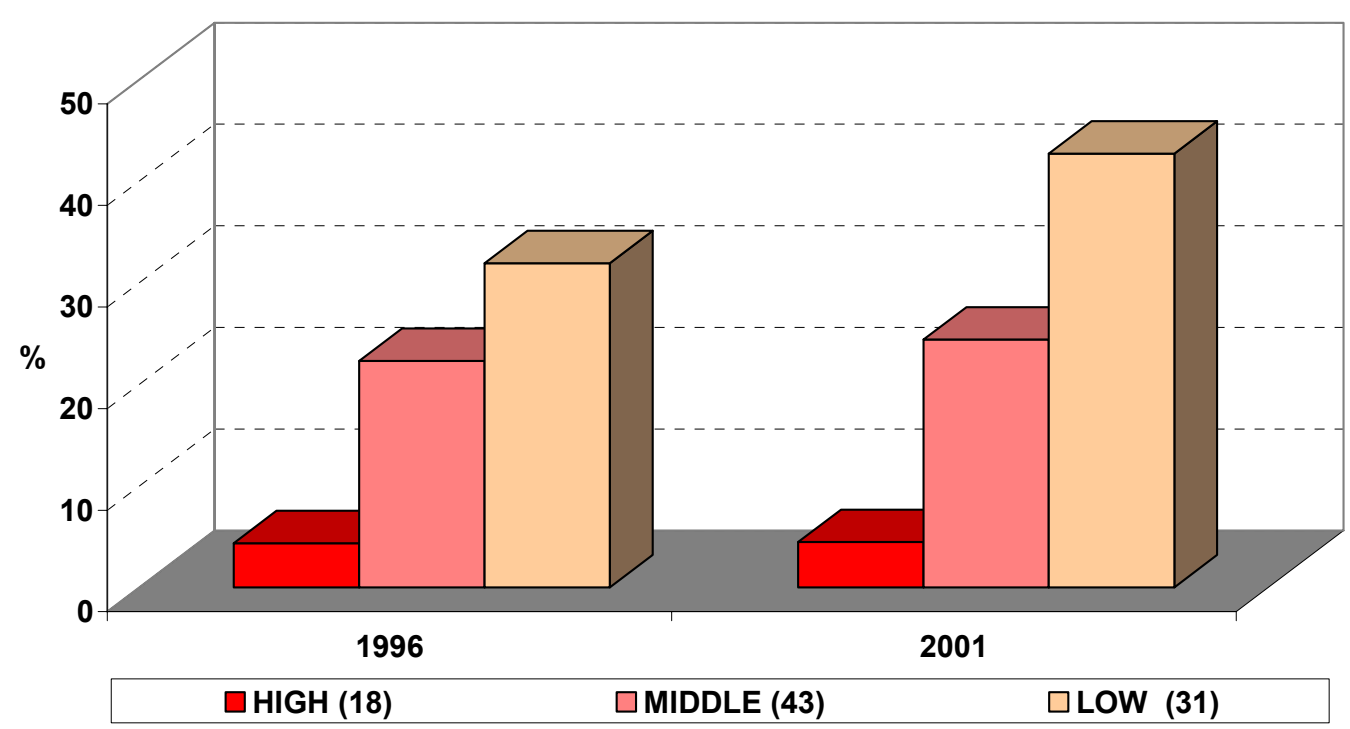

Source: IMF-IFS.

Note: For Austria, Haiti, Israel, Mexico, Macedonia, and Netherlands we take the 1997 data, and for Ghana, Italy, Norway, Tajikistan, and Uganda we take the 2000 data. High corresponds to OECD and non OECD countries.

Ex-post real interest rates may provide another indirect source of information: they tend to be high when actual inflation falls short of expectations, or also when inflation uncertainty is high. Figure III.8 plots ex-post real interest rates during the 1990s in industrial and developing countries. Though real interest rates in industrial countries were on a declining trend during the 1990s, this was not the case in developing countries. Among the latter, real interest rates remained persistently high and were higher at the end of the decade than at the beginning. ${ }^{35}$

\footnotetext{
${ }^{35}$ The real interest rate is measured as the (log) difference between the nominal interest rate and the oneperiod-ahead rate of GDP inflation.
} 
Figure III.8: Real Interest Rates, 1990-2001

(percent, medians by country income group)

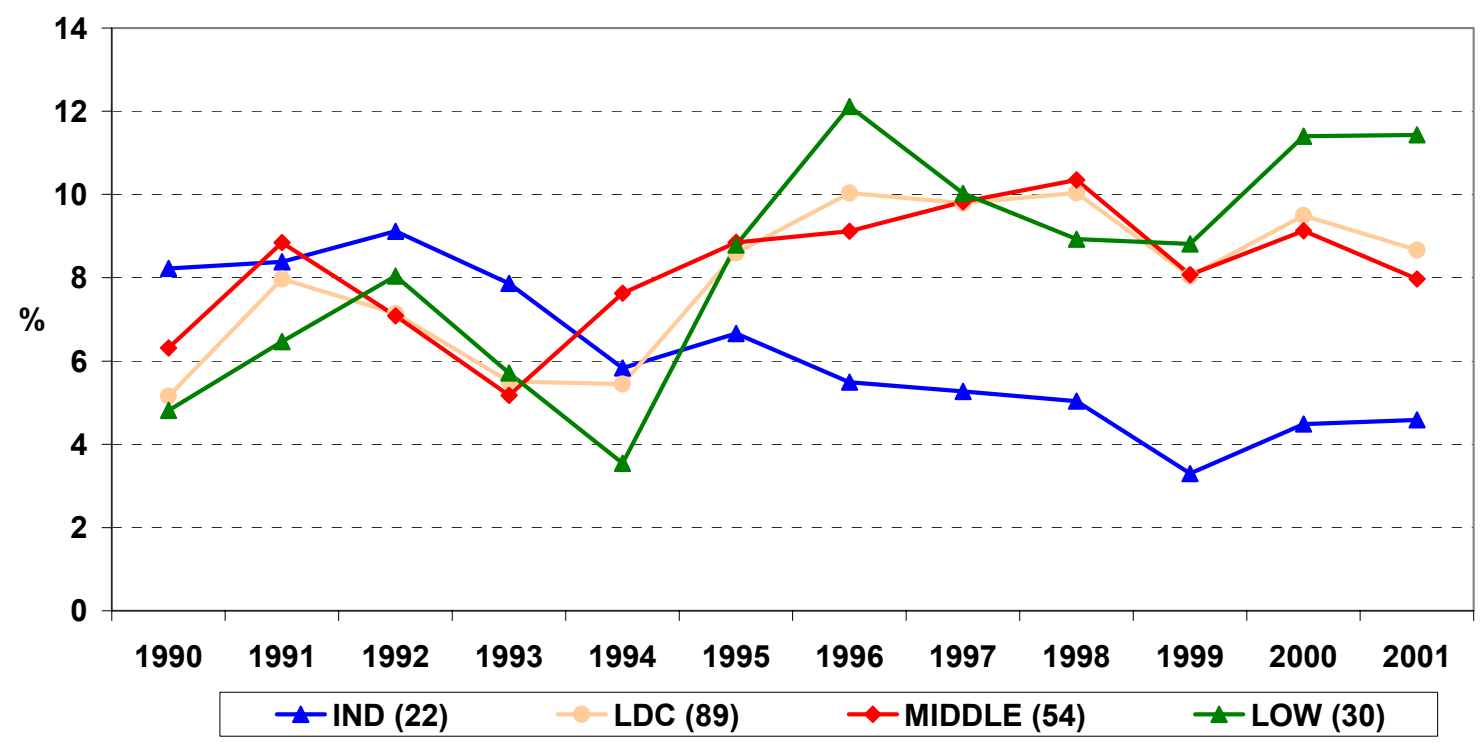

Sources: IMF-IFS and WDI-WB.

Note: The real interest rate is measured as the $(\mathrm{log})$ difference between the nominal interest rate and the one-period-ahead rate of GDP inflation.

Of course, both dollarization ratios and ex-post real interest rates reflect a variety of factors in addition to perceptions of nominal instability, so this evidence is only suggestive. ${ }^{36}$ But other indicators point in the same direction. As an extreme example, the currency premium on the Argentine peso was positive throughout the 1990s, and its magnitude became very large at times of turbulence, in spite of the supposedly irrevocable peg to the dollar enshrined in Argentina's Convertibility Law. ${ }^{37}$

\section{$v$. The transition to robust exchange rate arrangements has been anything but smooth}

Progress toward robust exchange rate regimes occurred at an uneven pace. Indeed, it probably was an early casualty of the search for macroeconomic stability. As already discussed, many countries adopted exchange rate-based stabilization strategies as a supposedly quick recipe for disinflation. These not only meant the adoption of singlecurrency pegs, but also made such pegs very difficult to adjust, since the credibility of the entire stabilization program was tied up with the stability of the peg. In effect, the defense of the peg sometimes became an end in itself, even when it was evident that it had outlived its usefulness. More flexible exchange rate arrangements -- i.e., arrangements lacking a pre-announced peg, with or without extensive central bank intervention, have too often been adopted only in the aftermath of currency crises.

\footnotetext{
${ }^{36}$ For example, the upward drift in interest rates likely reflects also the liberalization of financial systems in many developing countries over the 1990s.

${ }^{37}$ Schmukler and Servén (2002).
} 
The Mexico and East Asia crises, which involved the collapse of a variety of soft pegs, prompted what came to be known as the "two extremes" view of exchange-rate regimes, according to which only irrevocable pegs (including both currency boards and monetary unification or dollarization) and freely floating exchange rates were fit for survival in a world of increasing financial integration. There appeared to be an incipient flight away from intermediate regimes, ${ }^{38}$ based on the belief that the institutional foundation of monetary stability had to involve either arrangements taking discretion over money growth rates out of the hands of central banks, or the establishment of fully independent central banks with reputational stakes in low and stable inflation as well as the means (legal authority, policy instruments, human-resource capability) to achieve that goal. One explanation that was offered for this trend was that only these extreme regimes offered sufficient transparency to make exchange-rate policy easily verifiable and hence credible. $^{39}$

In reality, the late 1990s showed that neither dollarization nor currency boards offered a speedy shortcut to fiscal orthodoxy and nominal stability - instead of the slow and painful buildup of credibility required for an independent monetary policy - that their proponents had hoped. In particular, the Argentine episode brought into the open the threat to stability posed by inflexible exchange rates, which made adjustment to real disturbances exceedingly difficult. These shackles eventually undermine the sustainability of such rigid arrangements. Though less well known, the fate of the CFA franc during the first half of the 1990s provided another example (see Box III.1). But the establishment of a truly independent and effective central bank has not been a straightforward matter either. The creation of independent central banks in Venezuela in 1989 and in Mexico in 1993, for example, did not prevent the emergence of substantial political pressures for credit creation that contributed to currency crises in both of those countries in the first half of the 1990s. ${ }^{40}$

\section{vi. The reform agenda proved to be incomplete}

The preceding observations suggest that, as far as the traditional instruments of macroeconomic policy are concerned, the implementation of the reform agenda of the 1990s left much to be desired. But the agenda was also deficient in its very design. In particular, the experience of the 1990s showed reform to have been incomplete, in the sense that it left in place -- or worse yet, created -- important sources of macroeconomic fragility.

A particular area of fragility in which the policy-based stability agenda was incomplete is that of financial-sector soundness. While research has shown that an efficient domestic financial system is important for growth, the experience of the 1990s

\footnotetext{
${ }^{38}$ The flight out of intermediate regimes was documented, for example, by Fischer (2001). Whether it was in fact taking place has been disputed, however, particularly because alternative exchange regime classifications tend to provide sharply conflicting verdicts on regime trends. See Masson (2001) and Frenkel and Wei (2004) for further discussion.

${ }^{39}$ See Frankel et al (2001).

${ }^{40}$ Similar pressures were successfully applied on the supposedly independent Argentine central bank in 2001 on the eve of the collapse of the hard peg.
} 
strongly suggests that a sound one is indispensable for macroeconomic stability. The reform agenda of the early 1990s was incomplete in the sense that the central role of the financial system for macro stability was often ignored -- even though it should have been clear in light of the Southern Cone crises of the early 1980s. Thus to the standard policyoriented prescriptions for stability -- a solvent fiscal stance, low and stable money growth and robust exchange rate policies that nevertheless allow adjustment to shocks -- it is necessary to add the adoption of policies to foster a sound financial system. ${ }^{41}$

Aside from the shortcomings of macro policy stability in the traditional sense, stability in this particular sense -- i.e., that of assuring a sound domestic financial system -- was clearly not widely achieved. As a result, an important source of macroeconomic fragility was not only left in place but may, indeed, have even been magnified in the 1990 s, for reasons to be explained below. Inadequate attention to financial sector soundness often resulted in a domestic economic environment in which institutional problems involving moral hazard were rife, rendering both public as well as private balance sheets highly vulnerable to changes in the environment (interest-rate and exchange-rate changes) and posing a major obstacle to outcomes-based stability in a number of major countries. ${ }^{42}$ The proliferation of financial crises in the 1990 s reflects in part this missing piece of the reform agenda. Indeed, the incidence of systemic banking crises was even higher in the 1990s than in the 1980s, particularly in the second half of the decade (Figure III.9). ${ }^{43}$

\footnotetext{
${ }^{41}$ Indeed, in the wake of the crises of the 1990s the IMF has redefined its "core competencies" to include fiscal, monetary, exchange rate and financial sector policies.

${ }^{42}$ Ironically, under these circumstances incipient progress along conventional dimensions of macro stability such as disinflation may even have made financial crises more likely -- e.g., the use of the exchange rate as a nominal anchor may have encouraged agents to ignore exchange rate risk and in the case of "hard" pegs such as that of Argentina may have made it more difficult for regulators to induce financial institutions to factor such risk into their portfolio allocations without raising fears of a possible abandonment of the peg. ${ }^{43}$ The increasing incidence of banking crises is also documented by Bordo et al (2001).
} 
Figure III.9: Incidence of Systemic Banking Crises, Developing Countries, 1981-2000 (number of countries in crisis per year)

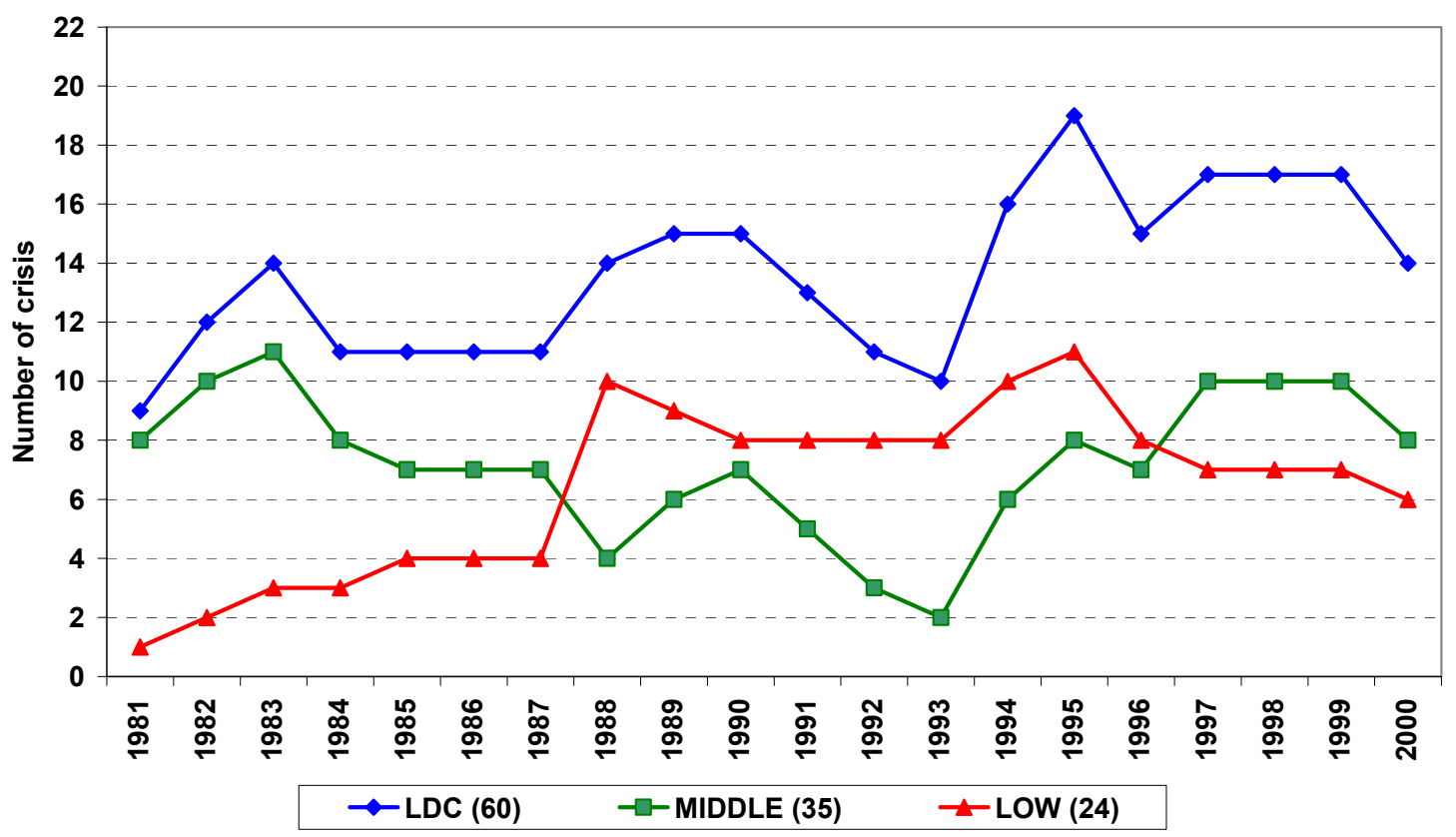

Source: Caprio and Klingebiel (2003).

But the frequency and severity of crises was also affected by an important change in the economic environment, namely increased capital mobility. This added another key source of fragility, by making economies vulnerable to sudden shifts in capital flows -such as those documented in section II. In fact, the combination of unsound policies in the financial sector and open capital accounts helps explain many characteristics of the crises of the 1990s. First, many of these crises were twin crises, simultaneously involving currency and banking collapses, often characterized by banking problems preceding a currency crash, which then fed back into a full-blown financial crisis. ${ }^{44}$ Second, many of these crises proved hard to predict on the basis of standard macroeconomic imbalances. Those that were hardest to predict -- especially the Mexican and Asian crises -- occurred in a setting where the main vulnerabilities concerned financial, rather than macroeconomic, variables and took the form of balance-ofpayments runs similar to traditional bank runs. ${ }^{45}$ Third, many of these crises were surprisingly severe. The deepest crises involved serious problems in the financial sector (Mexico, Asia, Ecuador and Turkey), in private sector balance sheets (Asia, Argentina), or fiscal insolvency (Ecuador, Argentina). Where none of these problems were present

\footnotetext{
${ }^{44}$ See Kaminsky and Reinhart (1999).

${ }^{45}$ In accordance with this, the recent analytical literature on crises continues to stress weak fundamentals as a prerequisite for the occurrence of crises, but emphasizes the key role of ingredients such as self-fulfilling expectations and multiple equilibria in triggering them; see e.g., Chari and Kehoe (2003) for a recent example. These views assign an increasingly important role to financial system imperfections in full-blown balance of payments crises; see for example Krugman (1999).
} 
and events took the form of a simple currency crash (as in Brazil), crisis-induced economic contraction was not as severe. ${ }^{46}$

\section{III.3 The Growth Payoff}

While the improvements in macroeconomic policies were limited -- as the preceding discussion has shown -- growth rates have indeed risen relative to the 1980s in many developing countries. The achievement is only a modest one, however, since growth in the 1980s was generally low, and for a majority of countries, growth rates in the 1990s remained well below those of the 1960s and 1970s. ${ }^{47}$

Is this growth payoff commensurate with the progress made with macroeconomic stability, or is it "disappointing"? It is important to keep in mind that industrial countries also grew much faster in the 1960s and 1970s than in the 1990s (Pritchett, 2004a). In addition, several issues need to be taken into account. First, as already explained, the growth payoff from macro stability depends on its perceived permanence. But, as just discussed, in many instances progress on the macro stability front was based on policy changes that were not perceived to be durable, and/or failed to include the reform of the institutions underlying macroeconomic policy-making. In this sense, the growth payoff that should have been expected from the type of stability that was actually achieved may have been overstated. Moreover, a vicious circle may have taken hold in some countries, in that the social consensus that made the policies possible -- and that is necessary to make them sustainable -- has faltered in the absence of a fairly prompt growth payoff.

Second, the search for macro stability -- narrowly defined -- may in some cases have actually been inimical to growth. As already noted, a preoccupation with reducing inflation induced some countries to adopt exchange-rate regimes that ultimately conflicted with outcomes-based stability. In other cases, as shown previously, a singleminded pursuit of macro stability may have come at the expense of growth-enhancing policies (e.g., an adequate provision of public goods), as well as of social investments that might have both increased the growth payoff and made stability more durable.

From this perspective, some economies may well have been over-stabilized, in both microeconomic and macroeconomic senses. From a microeconomic perspective, the presumed stability gains from further fiscal adjustments may not have justified the costs of foregoing key social and productive expenditures. From a macroeconomic perspective the narrow focus on stability may have precluded more progress toward countercyclical policies. The contrast between the significant fiscal adjustment achieved by most developing countries and the persistence of outcomes-based instability suggests that this factor may have been important.

\footnotetext{
46 The Russian crisis also turned out not to be very severe, but probably for exogenous reasons (i.e., the sharp recovery in world oil prices). More generally, there is evidence that twin crises are usually much more costly in terms of output than standard banking-only or currency-only crises; see Bordo et al (2001).

${ }^{47}$ Of course, in the short run the objectives of macro stability and growth may conflict with each other, as stabilization measures often entail an output cost over the near term. But the growth disappointment refers to the performance over the entire decade of the 1990s.
} 
Third, aside from whether the search for macro stability worked at cross-purposes with that for higher growth, the incompleteness of the macro reform agenda prevented the reduction in macroeconomic fragility that would have been required to fully translate policy-based stability into outcomes-based stability. Although overall macroeconomic volatility decreased among developing countries, extreme volatility actually rose during the 1990s, largely a reflection of a spate of crises during the decade. Moreover, the adverse impacts of extreme volatility on growth appear to exceed those of normal volatility. ${ }^{48}$ Thus, the growth payoff of the macroeconomic policy improvements achieved in the nineties was limited not only by their weak institutional underpinnings, but also by the extreme outcomes-based instability that emerged during the decade mainly as a result of the fragilities overlooked by an incomplete reform agenda.

Last, but not least, as argued in Section III.1, while macroeconomic stability may facilitate growth when other forces are driving the growth momentum, it is not enough to drive the growth process itself. That role has more to do with the various policies and institutions that shape the opportunities and incentives to engage in growth-enhancing activities (as discussed in Pritchett, 2004b). The importance of these complementary factors may not have been sufficiently appreciated early in the decade.

In sum, there is little reason to expect a simple, direct association between macro stability and growth, even if stability as measured by commonly used macro policy indicators is achieved. From this perspective, the limited growth payoff that emerged from the gains in macroeconomic stability achieved during the 1990 s may not be all that surprising.

\section{Lessons}

An important lesson from the 1990s is that the old verities concerning the importance of macroeconomic stability still hold true. While macroeconomic policy realizations are not all that matters for promoting economic growth, they clearly do matter. Perceived fiscal insolvency, high and unstable inflation and severely overvalued real exchange rates remain reliable recipes for extreme instability and slow growth. Despite the rather dramatic improvements in fiscal performance by large groups of developing countries, fiscal insolvency continued to produce 1980s-style crises in

\footnotetext{
${ }^{48}$ There are good reasons why crisis volatility (i.e., that due to large adverse shocks) should entail greater growth costs than normal volatility. On the one hand, with a given set of risk-management mechanisms, large shocks may be more difficult to absorb than small ones. These threshold effects of volatility have been found to be empirically relevant for investment (Sarkar, 2000; Servén, 2003). On the other hand, due to asymmetries built into the economy negative shocks have qualitatively different consequences than positive ones. A clear example is that of buffer stocks -- e.g., bank liquidity or international reserves: large adverse shocks (or a succession of small negative ones) can exhaust them and trigger an adjustment mechanism very different from the one involved for positive disturbances. The same applies to firms' net worth -- once it becomes negative, adjustment proceeds through bankruptcies, with the corresponding destruction of productive assets. Empirically, there is evidence that crisis-type volatility is significantly more adverse for growth than normal volatility (Hnatkovska and Loayza, 2004).
} 
countries as diverse as Argentina, Ecuador and Russia. In other countries, such as Pakistan, continued fiscal difficulties resulted in uncertainties that depressed investment and resulted in a prolonged period of slow growth. High inflation contributed to continuing macroeconomic instability in Ecuador, Turkey and Venezuela. Overvalued real exchange rates slowed growth and/or contributed to crises in Asia, Argentina, Mexico and Russia. In short, the experience of the 1990s has confirmed what we thought was clear at the end of the 1980s: macroeconomic policies matter for growth.

But as the discussion in the preceding pages has argued, the evidence of the 1990s also shows that macroeconomic policy realizations are not all that matter. Three other ingredients are critical: the institutional framework for monetary and fiscal policy, the prevention of macroeconomic fragilities and complementary pro-growth reforms. These elements are reviewed briefly below.

\section{IV.1 Institutions for Macroeconomic Policy Formulation}

The institutional context in which traditional macroeconomic policies are formulated is critical to achieving an adequate resolution of the tradeoff between policy credibility and flexibility. Both ingredients are required for the durable outcomes-based stability that ultimately matters for economic growth. In the fiscal area, an appropriate institutional setting should ensure transparency, sustainable solvency -- possibly through the adoption of fiscal rules -- flexibility and a pro-growth structure of government budgets. With respect to the monetary and exchange-rate policies within the purview of the central bank, the most successful institutional innovation to emerge in the 1990s seems to be one featuring an independent central bank with a floating exchange-rate regime and a publicly announced inflation target. The rest of this subsection examines more closely these aspects of the institutional framework for the formulation of traditional macroeconomic policies.

\section{a. Fiscal Policy}

\section{- Budgetary institutions and countercyclical fiscal policies}

The critical problem of shaping fiscal policy to be procyclical has not gone away during the 1990s. The phenomenon arises because, in the absence of strong budgetary institutions, a "tragedy of the commons" sets in during good times when government revenues are high -- no claimant on the government's budgetary resources internalizes the needs of fiscal solvency, and political imperatives thus cause the government to spend all of its resources (even to borrow) in the boom, leaving little margin of solvency to draw upon in order to finance fiscal deficits when times are bad.

What is required in such situations is to make it politically possible for the government to run fiscal surpluses during good times through the development of budgetary institutions and/or the implementation of fiscal rules that force the claimants to the government's resources to respect the government's intertemporal budget constraint, thus securing prudent fiscal responses to favorable shocks. 
Transparent fiscal rules embodied in the country's constitution or passed into law subject to change only by legislative supermajorities, with stipulated penalties for noncompliance, may be effective in many contexts. ${ }^{49}$ In countries where government revenues are heavily dependent on the prices of primary commodities, for example, institutions such as oil stabilization funds may need to be created to save windfalls. More generally, the key objective is to provide scope for automatic fiscal stabilizers to do their job. One promising example is Chile's Structural Surplus rule, which establishes fiscal policy targets adjusted for the variation in growth over the cycle.

Alternative proposals have focused on the creation of an independent "fiscal policy council." modeled along lines similar to an independent central bank, to set annual deficit limits. While this approach seems a logical implication of the international evidence that centralized fiscal authority helps resolve the commons problem, it has yet to be implemented. ${ }^{50}$ Whatever institutional arrangement is chosen, a basic policy step is to set fiscal deficit targets in cyclically-adjusted terms, a practice that could be encouraged by the IFIs.

Similar arguments apply to fiscal decentralization. While the local provision of public goods has much to recommend it, experience has shown that fiscal decentralization is also vulnerable to a commons problem unless institutional remedies are implemented that have the effect of imposing hard budget constraints on sub national governments. One way of reducing the procyclical bias in decentralized systems is to insulate resource-sharing arrangements from the effects of the cycle. ${ }^{51}$

Another important institutional aspect of fiscal policy is that of transparency. Uncertainty about the state of the fiscal accounts probably played a large role in generating the volatility of the risk premia that developing-country borrowers faced in international capital markets during the 1990s. Enhanced fiscal transparency is an important step in reducing such uncertainty. There is also evidence that more transparent budgetary procedures are associated with lower deficits and debt. ${ }^{52}$ The interests of fiscal transparency are well served by full accounting of the contingent liabilities of the public sector, including those of the central bank, and by explicit recognition of implicit liabilities - including those embedded in public pension systems.

\section{- Fiscal flexibility}

But another lesson of the nineties is that fiscal flexibility is as important as fiscal credibility. In the end, a credibly stable policy framework is not an end in itself. Instead, it matters for instrumental reasons; it makes it more feasible to achieve stability

\footnotetext{
${ }^{49}$ See Perry (2003).

${ }^{50}$ See Wyplosz (2002) for more details on the fiscal policy council proposal.

${ }^{51}$ See Sanguinetti and Tommassi (2003) for an analytical appraisal of alternative institutional setups. Burki et al (1999) review the international experience with various institutional arrangements in fiscally decentralized systems.

52 See Stein et al (1998) and Alt and Lassen (2003).
} 
of macroeconomic outcomes in a world in which destabilizing shocks are unavoidable. Stability in a policy sense is useful for its own sake only insofar as it avoids introducing self-inflicted types of shocks to aggravate an already unstable environment. But the value of policy stability is reduced if the credibility gains that such stability offers are not exploited in occasional departures from the medium-term stance of policies made necessary to counteract exogenous sources of instability.

This observation applies also to fiscal rules and similar arrangements discussed above. To be effective, they need to balance the objectives of credibility and flexibility. Simpler rules are more transparent and hence more easily verifiable. But at the same time they need to allow sufficient flexibility for fiscal policy to react to a changing economic environment. Indeed, overly rigid rules are unlikely to be sustainable or credible -- as shown by the increasing difficulties into which the European Stability Pact has run due to its neglect of the role of the macroeconomic cycle.

One lesson of the 1990s, however, is that it is difficult for governments to depart from the path of fiscal rectitude even when outcomes-based stability would make it desirable for this to happen, out of fear that markets may interpret this as a sign of fiscal lassitude. The tight fiscal policy adopted by the countries most heavily affected by the Asian financial crisis in the immediate aftermath of the crisis -- even while in the grip of severe recessions - is an example of this problem. ${ }^{53}$

Of course, it is hard to determine the extent to which those fears were well founded. To the extent that they were -- and that markets would indeed have reacted adversely -- the importance of the previous lesson on the implementation of improved fiscal institutions is enhanced, since the role of such institutions is precisely that of attaining the credibility required for governments to exercise fiscal flexibility without being unjustifiably punished by financial markets. If threats to confidence were overstated, however, then a key moral of the experience of the nineties is that it is important not to make a fetish out of fiscal stability as such. The need is only for as much stability as is required to convince the private sector that there has been a sustainable regime change. Once this is accomplished, the scope provided by gains in credibility to use macroeconomic policy instruments flexibly for stabilization purposes should be exploited to achieve outcomes-based stability.

\section{- Sustainable fiscal solvency and the avoidance of fiscal stopgaps}

An important lesson of the nineties is that the composition of fiscal adjustment matters both on the expenditure and revenue sides of the government's budget. In particular, a fiscal adjustment that is perceived to be durable must be based on sustainable policies on both sides of the budget, and on both sides of the budget it should be based on measures that are likely to enhance growth rather than retard it.

\footnotetext{
${ }^{53}$ A recent study by the IMF's Independent Evaluation Unit (IMF 2003c) suggests that the problem is more widespread. The study finds, in particular, that in "capital account crisis" cases, what appear in retrospect to have been cyclically-appropriate fiscal expansions were not undertaken in part out of fear of adverse effects on market confidence.
} 
With respect to sustainability, the key is that fiscal adjustments should be based on measures that the private sector can expect to increase the present value of future primary surpluses. Fiscal stopgaps of a temporary nature fall short of this criterion. Fiscal credibility cannot be achieved through policies that improve the government's budget outcomes for a year or two while leaving longstanding underlying fiscal problems unresolved.

On the other hand, some measures such as highly distortionary taxes (e.g., on external trade or on domestic financial transactions) or cuts in spending on productive infrastructure or human capital may raise the present value of the primary surplus at the expense of reduced growth. ${ }^{54}$ Indeed, reduced spending on health and education may have adverse effects on growth not just by reducing the accumulation of human capital, but also by undermining political support for sustaining responsible macroeconomic policies. Such measures defeat the ultimate objective of fiscal adjustment - namely, to allow the resumption of sustained growth. ${ }^{55}$

\section{b. Monetary Policy and Exchange Rate Regimes}

While the evidence suggests that low and stable rates of inflation are conducive to economic growth, theory suggests that what is most important is for the private sector to be convinced that low and stable inflation is here to stay. Evidence in the previous section indicated that maintaining this perception proved to be an elusive goal in the 1990s. As in the case of fiscal credibility, what is required is an appropriate institutional underpinning for price stability. However, one lesson of the 1990s is that the design of purely monetary arrangements cannot assure monetary policy credibility. Fiscal credibility is a necessary condition for monetary credibility, and not even the most rigid monetary arrangements (a currency board or de jure dollarization) provide a guarantee of hard government budget constraints. On the other hand, a credible commitment to fiscal solvency is not the same thing as a credible commitment to price stability, since fiscal solvency is in principle compatible with relatively high and fluctuating levels of seigniorage revenue. Thus there is a separate role for monetary institutions that can credibly preclude excessive reliance on seigniorage revenues.

\footnotetext{
${ }^{54}$ These policies may fail to raise the present value of future primary surpluses if their negative effects on economic growth have a sufficiently adverse impact on growth in government revenues; see Easterly and Servén (2003).

${ }^{55}$ Perhaps the most dramatic example of this problem is the failure of the South African government to address the country's alarming rate of HIV infection more aggressively, an outcome that some critics have blamed on fears of budgetary costs. This situation may not only have undermined the country's long-term growth through a variety of possible channels, but has also weakened support for the government's pursuit of macroeconomic stability. Similarly, timidity on the part of Latin American countries in addressing poverty problems on the continent, partly driven by fiscal stringency, has contributed to the failure of income distribution to improve in the region during the 1990s. This outcome has combined with the region's disappointing growth performance to weaken support in Latin America for the reform agenda of the past decade.
} 
The 1990s have shown that there are no institutional shortcuts to monetary credibility. It has to be earned the hard way: through anti-inflationary performance. In this regard, the institution of an independent central bank operating a floating exchange rate -- and with a commitment to price stability that takes the form of a publiclyannounced inflation target -- appears to have been a successful innovation among emerging-market economies during the past decade. Such arrangements are currently maintained by Brazil, Chile, Colombia, Korea, Mexico, Peru, South Africa and Thailand. This institutional arrangement has the important advantages of flexibility (since the central bank is not constrained in how it attains its inflation target) as well as of commitment (since the central bank's prestige is publicly put on the line). Most importantly, the adoption of floating exchange rates and inflation targets allows the domestic authorities to establish their anti-inflationary credibility the hard way -- i.e., by establishing a track record - rather than by attempting to import it through some form of exchange-rate peg. The longest-running of these arrangements -- in Chile -- has been remarkably successful in maintaining price stability throughout the decade of the nineties, while avoiding severe episodes of real exchange-rate volatility. More recent converts to this type of nominal institutional arrangement have also been quite successful since its (admittedly recent) adoption.

\section{IV.2 Robustness: The Scope of the Macroeconomic Reform Agenda}

Overall, an important lesson from the experience of the 1990s is that the quality of traditional macro policy-based stability matters. A particularly important corollary is that an appropriate institutional setting for formulation of fiscal, monetary and exchange rate policies is indispensable. But beyond these traditional macroeconomic policies, the proliferation of crises during the 1990s has made it clear that policy also needs to attend to robustness issues. That is, the stability agenda should encompass not just fiscal, monetary, and exchange rate policies, but also policies designed to reduce macroeconomic (especially financial) fragility. This includes, in particular, policies directed toward the domestic financial system and toward the management of the country's capital account, both of which have been shown to have important implications for macroeconomic fragility and thus for outcomes-based macroeconomic stability.

\section{a. The Domestic Financial Sector}

Concerning the policy regime governing the domestic financial sector, the experience of the last decade has once again underlined the importance of an appropriately regulated and supervised domestic financial system to avoid macroeconomic vulnerability arising from the concentration of lending in highly risky activities or the emergence of balance sheet mismatches.

While the repressed domestic financial sectors that prevailed in many developing countries during previous decades (as documented in Ramachandran, 2004) were undoubtedly inimical to economic growth, an important old lesson that was re-learned over the past decade is that reforming the domestic financial sector is not synonymous with liberalizing it. In particular, removing restrictions on entry, on the setting of 
interest rates and on the allocation of the portfolios of financial institutions without at the same time strengthening the institutional framework in which the financial sector operates creates excessive scope for moral-hazard lending, resulting in financial-sector balance sheets that are fragile and vulnerable to insolvency in response even to moderate macroeconomic shocks.

As has been widely recognized, the appropriate institutional framework involves clear and secure property rights, an accessible, efficient and impartial legal system to enforce contracts, appropriate legal protection for creditors, well-specified accounting and disclosure standards, a regulatory system that screens entrants while encouraging competition, imposing adequate capital requirements and preventing excessively risky lending and a supervisory system that can effectively monitor the lending practices of domestic financial institutions. The key lesson is that the pace of liberalization for domestic financial systems that have not already been liberalized should be modulated to reflect the quality of the institutional framework governing the domestic financial sector and that improving the quality of this framework deserves high priority in the macroeconomic reform agenda.

\section{b. The Capital Account}

With respect to the capital account, the management of a county's integration into international financial markets remains a controversial part of the institutional agenda. As is true in the case of the domestic financial sector, enhanced integration with world financial markets promises many benefits, but the costs -- in the form of macro risks -may outweigh those benefits when the domestic institutional structure is defective. Increased financial openness makes it easier for investors to inflict swift and severe punishment on countries in response to perceptions, warranted or not, that their macroeconomic policies are off-track. However, countries' misguided attempts to ride the wave of short-term capital have also played a major role in some crisis episodes. ${ }^{56}$

Indeed, despite the theoretical arguments concerning the gains from capital account openness, the empirical evidence on whether it has in fact been conducive to growth in the international experience is inconclusive. ${ }^{57}$ Moreover, the evidence suggests that, contrary to theoretical predictions, it has not helped reduce macroeconomic (especially consumption) volatility. ${ }^{58}$

\footnotetext{
${ }^{56}$ In the words of Larry Summers, referring to the role of Mexico's Tesobonos on the eve of the Tequila crisis: "[...] the situation was not one of an innocent country somehow overwhelmed by a flood of capital from the herd of speculators, but rather a situation of countries who, for domestic policy reasons, made very, very active efforts to dine with the devil of speculators -- and ended on the menu" (Speaking from Experience, lecture delivered in Washington DC on February 2, 2004). Electronic link: http://info.worldbank.org/etools/bspan/PresentationView.asp?PID=1015\&EID=328

${ }^{57}$ The most comprehensive empirical study is that of Edison et al (2002), who fail to find robust evidence of a significant growth impact. Prasad et al (2003) argue that there may be "threshold effects": countries with sound policies and institutions are more likely to derive a growth benefit from financial integration. ${ }^{58}$ See Kose et al (2003).
} 
The desire to avoid macroeconomic fragility makes a strong case for institutional arrangements regarding the capital account that at least prevent the emergence of maturity mismatches in a country's external balance sheet, since such mismatches can make the country vulnerable to creditor runs analogous to bank runs. ${ }^{59}$ The question is how to preclude them. A difficulty in achieving this objective is that short maturities are attractive to creditors as a means of monitoring borrowers and controlling their behavior precisely when asymmetric information and moral hazard problems are serious. Under these circumstances, therefore, short-maturity borrowing will arise endogenously because it will be substantially less costly to borrowers than long-term loans. The problem is, of course, that voluntary short-maturity loans between private parties fail to take into account the social costs associated with the risk of creditor runs.

One possible way to deal with maturity mismatches is for the public sector to accumulate large stocks of foreign-currency assets (foreign exchange reserves) to offset liquid liabilities incurred by the private sector. While this approach is at present being pursued by some East Asian countries, as well as Chile, it is likely to be very expensive. Holding large volumes of low-yielding, short-term assets instead of (illiquid) long-term investment entails serious opportunity costs and even fiscal ones, as the purchase of foreign exchange reserves needs to be sterilized by the sale of typically higher-yielding domestic government liabilities. In this case, the incentives that give rise to short-term borrowing are left in place, and the costs of insuring against creditor runs are ultimately borne by taxpayers.

An alternative route is to discourage the private sector from incurring short-term external liabilities in the first place through restrictions on short-term capital inflows, or to make those liabilities effectively less liquid in times of crisis through restrictions on short-term capital outflows. Because both of these policies would tend to increase the cost of short-term loans, they effectively operate by internalizing the systemic costs associated with the risk of creditor runs. The questions are, of course, whether such restrictions can be designed to be minimally distortionary with respect to other types of capital flows and whether they can be made effective.

These questions have attracted considerable attention in recent years. In the case of restrictions on inflows, the empirical evidence is modestly reassuring. Cross-country and country-specific studies generally conclude that inflow restrictions such as unremunerated reserve requirements (e.g., the Chilean encaje) tend to have no significant effect on the overall volume of inflows but do affect their composition, reducing the share of short-term flows in the total. ${ }^{60}$ In contrast, evidence on the effects of restrictions on outflows is much less conclusive.

\footnotetext{
${ }^{59}$ These runs played a key role in the East Asian crisis; see for example Rodrik and Velasco (1999). Mismatches may reflect not only an inadequate borrowing strategy, but also the reluctance of investors to lend long-term in the face of a macro-financial framework deemed suspect.

${ }^{60}$ The reason is that a uniform reserve requirement is more onerous for short-term transactions than for the rest. Montiel and Reinhart (1999) review the cross-country evidence on the effectiveness of inflow restrictions.
} 
The available evidence, then, suggests that restrictions on short-term capital inflows may have a role to play in the achievement of outcomes-based macroeconomic stability in developing countries. However, it is important to be aware of the fact that such restrictions do entail economically significant costs to private agents, in terms of their impact on the availability and/or price of financing. ${ }^{61}$

In addition to maturity mismatches, external borrowing also aggravates the problem of currency mismatches, to the extent that foreign lenders are less willing to accept the risk of currency depreciation than are domestic lenders and thus refuse to extend credit in the borrowers' currency. The solution, however, is not to restrict access to external borrowing. As in the case of dollarization, in the short run the key is to promote the efficient distribution of this exchange-rate risk within the domestic economy by ensuring -- through regulatory means -- that it is appropriately priced and therefore borne by those best able to bear it (typically agents holding foreign currency assets -including exporters -- or those with a high degree of risk tolerance). In the case of sovereign borrowing, the priority is to ensure that borrowing decisions do recognize the existence and potential cost of exchange rate risk.

In the longer term, a larger role in ameliorating the problem of currency mismatches would be assumed by institutional changes that promote credible nominal stability, thus mitigating exchange-rate risk. The experience of emerging economies that are starting to be able to denominate external borrowing in domestic currency -- such as South Africa -- is consistent with this perspective. IFIs could help advance this process by denominating their lending in local currency, a practice that is already starting with some emerging markets.

\section{IV.3 Complementarities Among Pro-Growth Policies}

But the burden of jump-starting growth in developing countries has to fall primarily on pro-growth policies outside the macroeconomic arena. Such policies include, for example, the implementation of an open international trade regime, the adoption of national innovation policies, well-functioning factor markets and an investorfriendly legal and regulatory environment. In some cases, those policies actually facilitate the adoption of reforms aimed at macroeconomic stability - e.g., disinflation or the correction of a real misalignment are easier and less costly to achieve with wellfunctioning labor and financial markets.

The key lesson is that policies of this type are mutually complementary with policies that focus on the creation and preservation of macroeconomic stability. An unstable macroeconomic environment tends to undermine the growth benefits of such policies. Nonetheless, what we have learned from the 1990s is that macro stability alone is not enough; policies outside the macroeconomic arena are themselves indispensable to harvest the fruits of macroeconomic stability in the form of sustained high rates of economic growth.

\footnotetext{
${ }^{61}$ In the Chilean case, Forbes (2003) argues that these costs were substantial. Johnson and Mitton (2002) find that in the case of Malaysia capital controls served to protect cronyism.
} 


\section{Box III.1. The Devaluation of the CFA Franc}

The CFA Zone consists of 14 West African countries that share a common currency, the CFA franc. The 14 countries are divided into three groups: the West African Economic and Monetary Union (WAEMU), the central African Economic and Monetary Union (CAEMC), and Comoros. The WAEMU consists of seven former French colonies in West Africa (Benin, Burkina Faso, Ivory Coast, Mali, Niger, Senegal and Togo). The CAEMC, in turn, includes Cameroon, the Central African Republic, Chad, the Congo, Equatorial Guinea, and Gabon. The WAEMU and CAEMC have separate regional central banks, known by their French acronyms $\mathrm{BCEAO}$ and BEAC, each of which issues its own version of the CFA franc, as does Comoros separately.

Most of the countries in the CFA Zone have shared the CFA franc as a freely circulating common currency since pre-independence times. From 1948 to 1993, the CFA franc was pegged to the French franc at the value of CFAF $50=$ F 1 . Since, as the former colonial power, France has historically dominated the external trade of the member economies of the Zone, the fixity of the exchange rate against the French franc reflects, at least in part, a desire to minimize transactions costs in international trade But it has also served to provide a nominal anchor for these economies.

The fixed exchange rate against the French franc has effectively been guaranteed by France: the regional central banks maintain their foreign exchange reserves at the French Treasury and the latter ensures unlimited convertibility of the CFA franc into French francs through an "operations account" that essentially lends the regional central banks the French francs required to ensure convertibility. In return, France is represented on the banks' Boards of Directors.

The CFA Zone, unlike the eurozone, did not impose explicit fiscal conditions for membership in the union. However, some coordination of fiscal policies to prevent spillover problems has been attempted through the lending policies of the zone's central banks. This has taken two forms. First, outstanding BCEAO credit to the governments of each of the member countries is restricted to be no more than 20 percent of that government's tax receipts in the previous year. Second, each year the BCEAO's Board of Directors formulates plans for credit expansion to each member country that includes a ceiling on the flow of credit to each government. Notice that, if effective, these restrictions would indeed help to safeguard the BCEAO from pressures for excessive monetary expansion driven by the fiscal needs of individual member countries, but unlike the Maastricht treaty, which circumscribes overall fiscal deficits and total public debt, they still leave individual countries with substantial discretion over their overall fiscal policies, because member country governments retain the latitude to finance fiscal deficits through means other than borrowing from the BCEAO.

The common currency appears to have been reasonably effective in maintaining financial discipline in the member countries for an extended period. Until the mid 1980s, these countries enjoyed relatively lower inflation and more sustained economic growth than other Sub-Saharan African countries, despite the persistence of certain structural rigidities, particularly in labor markets. But the shortcomings of the "hard" peg against the French franc became apparent in the mid-1980s, when the Zone was hit by two external shocks: a sharp deterioration in the terms of trade of its member countries arising from a decline in the world prices of its primary export commodities, and a strong appreciation of the French franc against the U.S. dollar. These shocks placed strong pressures on fiscal outcomes in the Zone, heavily dependent on commodity 
revenues and trade taxes. Member countries' failure to impose an orderly correction, partly due to their inability to adjust public sector wages downward, led to sharply higher fiscal and current account deficits, large increases in external debt, and deteriorating growth performance relative to other countries in Sub-Saharan Africa. The CFA franc became substantially overvalued.

To reverse the worsening economic performance, the overvaluation had to be eliminated, and this eventually led to the first major devaluation of the CFA franc, implemented on January 12,1994 , when the official parity was changed to CFAF $100=\mathrm{F} 1$. The devaluation was accompanied by several ancillary measures, including measures to improve fiscal performance through a broadening of the tax base and a reduction of expenditures (mainly in the form of the public wage bill and subsidies to public enterprises), as well as structural reforms focused on trade liberalization, increasing flexibility in labor markets, reducing the direct role of government in production, and restructuring financial sectors.

The results of the devaluation were on the whole quite positive. Inflation accelerated briefly in 1994, but quickly converged to single-digit levels. Consequently, the real effective depreciation of the CFE franc in 1994 amounted to about 30 percent (Clement et al, 1996). Real GDP growth, which had been negative in 1993, averaged 1.3 percent for the Zone as a whole in 1994, and accelerated subsequently. Overall fiscal deficits, which had peaked at about 8 percent of GDP in 1993, had fallen to just over 2 percent of GDP by 1996. Meanwhile, while investment increased slightly in the region as a whole, a substantial increase in saving rates resulted in a reduction in the current account deficit of some 2 percent of GDP between 1993 and 1996, and coupled with capital repatriation and renewed external assistance, the upshot was a large increase in the foreign exchange reserves of the BCEAO and BEAC. 


\section{References}

Aalt, J., and D. Lassen (2003): "Fiscal Transparency and Fiscal Policy Outcomes in OECD Countries." Economic Policy Research Unit Working Paper 2003-02.

Blanchard, O., and F. Giavazzi (2003): "Improving the Stability and Growth Pact Through Proper Accounting of Public Investment." Center for Economic and Policy Research Discussion Papers No. 4220.

Bordo, M., B. Eichengreen, D. Klingebiel, and M. S. Martinez-Peria, (2001): "Is the Crisis Problem Growing More Severe?" Economic Policy: A European Forum 32 (April): 51-75

Buiter, W. (1990): Principles of Budgetary and Financial Policy. Cambridge. Massachusetts Institute of Technology Press: MA

Burki, J., G. Perry, and W. Dillinger (1999): Beyond the Center: Decentralizing the State. The World Bank: Washington, DC.

Calderón, C., R. Duncan, and K. Schmidt-Hebel (2003): "The Role of Credibility in the Cyclical Properties of Macroeconomic Policies in Emerging Economies." Mimeo, Central Bank of Chile: Santiago de Chile.

Calvo, G. (1998): "Capital Flows and Capital Market Crises: The Simple Economics of Sudden Stops." Journal of Applied Economics 1: 35-54.

Calvo, G., and C. Reinhart (2000): "When Capital Inflows Come to a Sudden Stop: Consequences and Policy Options." In P. Kenen and A. Swoboda (eds.), Key Issues in Reform of the International Monetary System. International Monetary Fund: Washington, DC.

Campillo, M., and J. Miron (1997): “Why Does Inflation Differ across Countries?" In C. Romer and D. Romer (eds.), Reducing Inflation: Motivation and Strategy. University of Chicago Press: Chicago, IL.

Caprio, G., and D. Klingebiel (2003): "Bank Insolvencies: Cross-Country Experience." Mimeo, The World Bank: Washington, DC.

Chari, V., and P. Kehoe (2003): "Hot Money.” Journal of Political Economy 111 (6): 1262-1292.

Clement, J. A.P., J. Mueller, S. Cosse, and J. Le Dem (1996): “Aftermath of the CFA Franc Devaluation.” IMF Occasional Paper 138 (May). International Monetary Fund: Washington, DC.

Cohen, D., and R. Portes (2003): "Dealing with Destabilizing 'Market Discipline'." Center for Economic and Policy Research Discussion Paper No. 4280.

Cukierman, A., G. Miller, and B. Neyapti (2001): "Central Bank Reform, Liberalization and Inflation in Transition Economies: An International Perspective." Center for Economic and Policy Research Discussion Paper No. 2808.

Cukierman, A., S. Webb, and B. Neyapti (1992): "Measuring the Independence of Central Banks and its Effect on Policy Outcomes." World Bank Economic Review 6 (3): 353-398.

De Ferranti, D., G. Perry, I. Gill, and L. Servén (2000): Securing Our Future. The World Bank: Washington, DC.

De Haan, J., and W. Koi (2000): "Does Central Bank Independence Really Matter? New Evidence for Developing Countries Using a New Indicator." Journal of Banking and Finance 24 (4): 643-664. 
De la Torre, A., and S. Schmukler (2003): "Coping with Risk through Mismatches: Domestic and International Financial Contracts for Emerging Economies." Mimeo. The World Bank: Washington, DC.

Easterly, W. (1999): “When is Fiscal Adjustment an Illusion?” Economic Policy 14 (28): 55-76. (2001): “The Lost Decade: Developing Countries' Stagnation in Spite of Policy Reform." Journal of Economic Growth 6: 135-157.

Easterly, W., and S. Fischer (2001): "Inflation and the Poor." Journal of Money, Credit, and Banking 33: 160-179.

Easterly, W., R. Islam, and J. Stiglitz (2001): "Volatility and Macroeconomic Paradigms for Rich and Poor." In J. Dréze (ed.), Advances in Macroeconomic Theory. Palgrave: New York.

Easterly, W., and L. Servén (eds.) (2003): The Limits of Stabilization: Infrastructure, Public Deficits, and Growth in Latin America. Stanford University Press: Palo Alto, CA.

Edison, H., R. Levine, L. Ricci, and T. Sloken (2002): "International Financial Integration and Economic Growth.” National Bureau of Economic Research Working Paper No. 9164. National Bureau of Economic Research: Cambridge, MA.

Fischer, S. (2001): “Exchange Rate Regimes: Is the Bipolar View Correct?” Journal of Economic Perspectives 15(2): 3-24.

Forbes, K. (2003): "On the Cost of the Chilean Capital Controls: Increased Financial Constraints for Smaller Trade Firms." National Bureau of Economic Research Working Paper No. 9777. National Bureau of Economic Research: Cambridge, MA.

Frankel, J., and A. Rose (1996): "Currency Crashes in Emerging Markets: Empirical Indicators." National Bureau of Economic Research Working Paper No. 5437. National Bureau of Economic Research: Cambridge, MA.

Frankel, J., E. Fajnzylber, S. Schmukler, and L. Servén (2001): "Verifying Exchange Rate Regimes." Journal of Development Economics 66 (2): 351-385.

Frankel, J., and S. Wei (2004): "Managing Macroeconomic Crises: Policy Lessons." In J. Aizenmann and B. Pinto (eds.), Managing Volatility and Crises: a Practitioner's Guide. The World Bank, to be submitted to Cambridge University Press.

Gutiérrez, E. (2003): "Inflation Performance and Constitutional Central Bank Independence: Evidence from Latin America and the Caribbean.” IMF Working Paper 03/53. International Monetary Fund: Washington, DC.

Halac, M., and S. Schmukler (2003): "Distributional Effects of Crises: the Role of Financial Transfers.” Policy Research Working Paper 3173. The World Bank: Washington, DC.

Hnatkovska, V., and N. Loayza (2004): "Volatility and Growth." Policy Research Working Paper 3184. The World Bank: Washington, DC.

Hutchison, M., and I. Noy (2002): “Sudden Stops and the Mexican Wave.” Economic Policy Research Unit Working Paper Series No. 02-12.

Inter American Development Bank (IADB) (1995): Overcoming Volatility in Latin America. Inter American Development Bank: Washington, DC.

International Monetary Fund (IMF) (2002): "Financial Stability in Dollarized Economies." Mimeo. 
(2003a): World Economic Outlook: Public Debt in Emerging Markets. International Monetary Fund: Washington, DC.

(2003b): Fiscal Adjustment in IMF-supported Programs. International Monetary Fund: Washington, DC.

(2003c): The IMF and Recent Capital Account Crises. International Monetary Fund: Washington, DC.

Ize, A., and E. Levy-Yeyati (1998): "Financial Dollarization." IMF Working Paper No. 1998/28. International Monetary Fund: Washington, DC.

Johnson, S., and T. Mitton (2002): "Cronyism and Capital Controls: Evidence from Malaysia." Journal of Financial Economics 67 (2): 351-382.

Kaminsky, G., and C. Reinhart (1999): "The Twin Crises: the Causes of Banking and Balance of Payments Crises." American Economic Review 89 (3): 473-500.

Kharas, H., and B. Pinto (2001): “An Analysis of Russia's 1998 Meltdown: Fundamentals and Market Signals.” Brookings Papers on Economic Activity 1 (2001): 1-50

Kose, A., E. Prasad, and M. Terrones (2003): "Financial Integration and Macroeconomic Volatility.” IMF Staff Paper No. 50: 119-142. International Monetary Fund: Washington, DC.

Kraay, A., and V. Nehru (2003): "When is External Debt Sustainable?" World Bank Policy Research Working Paper 3200, February 2004. The World Bank: Washington, DC.

Krugman, P. (1999): "Balance Sheets, the Transfer Problem and Financial Crises.” In P. Isard, A. Razin, and A. Rose (eds.), International Finance and Financial Crises. Partly reprinted from International Tax and Public Finance, Vol. 6, no. 4. Boston; Dordrecht and London: Kluwer Academic. International Monetary Fund: Washington, DC.

Lane, P. (2003): "The Cyclical Behavior of Fiscal Policy: Evidence from the OECD." Journal of Public Economics 87: 2661-2675.

Laursen, T., and S. Mahajan (2004): "Volatility, Income Distribution and Poverty." In J. Aizenmann and B. Pinto (eds.), Managing Volatility and Crises: a Practitioner's Guide. The World Bank: Washington, DC.

Masson, P. (2001): “Exchange Rate Regime Transitions.” Journal of Development Economics 64 (2): 571-586.

Mendoza, E. (2001): “Credit, Prices, and Crashes: Business Cycles with a Sudden Stop.” National Bureau of Economic Research Working Paper No. 8338. National Bureau of Economic Research: Cambridge, MA.

Montiel, P. (2002): "Ecuador: Una Estrategia de Crecimiento para una Economía Dolarizada," Cuestiones Económicas 18 (3): 133-225.

Montiel, P., and C. Reinhart (1999): "Do Capital Controls and Macroeconomics Policies Influence the Volume and Composition of Capital Flows? Evidence from the 1990s." Journal of International Money and Finance 18 (4) (August): 619-635

Mussa, M. (2002): Argentina and the Fund: From Triumph to Tragedy. Institute for International Economics: Washington, DC.

Perry, G. (2003): “Can Fiscal Rules Help Reduce Macroeconomic Volatility?” World Bank Policy Research Working Paper Series No. 3080. The World Bank: Washington, DC. 
Perry, G., and L. Servén (2003): "The Anatomy of a Multiple Crisis: Why was Argentina Special and What Can We Learn from It?” World Bank Policy Research Working Paper No. 3081. The World Bank: Washington, DC.

Prasad, E., K. Rogoff, S. Wei, and M. Kose (2003): "Effect of Financial Globalization on Developing Countries: Some Empirical Evidence." Unpublished manuscript. International Monetary Fund: Washington, DC.

Pritchett, L. (2004a): "The Grist and the Mill for the Lessons of the 1990s." In G. Nankani and R. Zagha (eds.), The Growth Experience: What Have We Learned From the 1990s? (Chapter 1). The World Bank: Washington, DC. (2004b): "Policy Reforms and Growth Performance: What Have We Learned?" In G. Nankani and R. Zagha (eds.), The Growth Experience: What Have We Learned From the 1990s? (Chapter 7). The World Bank: Washington, D.C.

Ramachandran, S. (2004): "Lessons from Crises: 1994 Mexico, 1997 East Asia, 1999 Russia, 2000 Turkey, 2001 Argentina, 2002 Brazil.” In G. Nankani and R. Zagha (eds.), The Growth Experience: What Have We Learned From the 1990s? (Chapter 6). The World Bank: Washington, DC.

Ramey, G., and V. Ramey (1995): "Cross-country Evidence on the Link between Volatility and Growth." American Economic Review 85 (5): 1138-1151

Reinhart, C., K. Rogoff, and M. Savastano (2003): “Addicted to Dollars.” National Bureau of Economic Research Working Paper 10015. National Bureau of Economic Research: Cambridge, MA.

Rodrik, D. (2001): "Why Is There So Much Economic Insecurity in Latin America?" CEPAL Review 73: 7-30.

Rodrik, D., and A. Velasco (1999): "Short-term Capital Flows." National Bureau of Economic Research Working Paper No. 7364. National Bureau of Economic Research: Cambridge, MA.

Sanguinetti, P., and M. Tommassi (2003): "Intergovernmental Transfers and Fiscal Behavior: Insurance versus Aggregate Discipline.” Journal of International Economics 62 (1): 149-170.

Sarkar, S. (2000): "On the Investment-uncertainty Relationship in a Real Options Model." Journal of Economic Dynamics and Control 24 (2): 219-225.

Schmukler, S., and L. Servén (2002): "Pricing Currency Risk under Currency Boards.” Journal of Development Economics 69 (2): 367-391.

Servén, L. (2003): "Real Exchange Rate Uncertainty and Private Investment in LDCs." Review of Economics and Statistics 85 (1): 212-218.

Shvets, O. (2004): "Something Special About the 1990s?" In G. Nankani and R. Zagha (eds.), The Growth Experience: What Have We Learned From the 1990s? (Chapter 2). The World Bank: Washington, DC.

Stein, E., E. Talvi, and A. Gristani (1998): "Institutional Arrangements and Fiscal Performance: The Latin American Experience." National Bureau of Economic Research Working Paper No. 6358. National Bureau of Economic Research: Cambridge, MA.

Sturm, J, and J. de Haan (2001): “Central Bank Independence and Inflation in Developing Countries." Center for Economic Studies and the Ifo Institute for Economic Research Working Paper No. 511.

Talvi, E. (1997): “Exchange-rate Based Stabilization with Endogenous Fiscal Response." Journal of Development Economics 54 (1): 59-75. 
Talvi, E., and C. Vegh (2000): “Tax Base Variability and Pro-cyclical Fiscal Policy.” National Bureau of Economic Research Working Paper No. 7499. National Bureau of Economic Research: Cambridge, MA.

Wyplosz, C. (2002): "Fiscal Discipline in Emerging Market Economies: How to Go about It?" Mimeo. Graduate Institute for International Studies, Geneva and Center for Economic and Policy Research. 